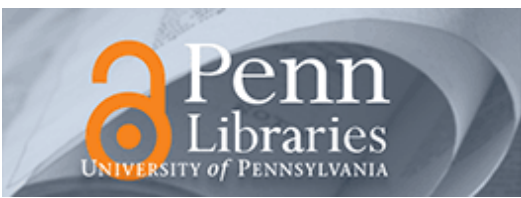

University of Pennsylvania ScholarlyCommons

\title{
Retirement in Japan and the United States: Cross- national Comparisons using the Japanese Study of Aging and Retirement (JSTAR) and the U.S. Health and Retirement Study (HRS)
}

Olivia S. Mitchell

The Wharton School, University of Pennsylvania, mitchelo@wharton.upenn.edu

John WR Phillips

National Institute on Aging, john.phillips@nih.gov

Follow this and additional works at: https://repository.upenn.edu/prc_papers

Part of the Economics Commons

Mitchell, Olivia S. and Phillips, John WR, "Retirement in Japan and the United States: Cross-national Comparisons using the Japanese Study of Aging and Retirement (JSTAR) and the U.S. Health and Retirement Study (HRS)" (2013). Wharton Pension Research Council Working Papers. 111.

https://repository.upenn.edu/prc_papers/111

The authors thank Hidehiko Ichimura and Satoshi Shimizutani for their assistance in using the new Japanese Study of Aging and Retirement. Excellent programming assistance was provided by Yong Yu. The Japanese Study of Aging and Retirement (JSTAR) was conducted by the Research Institute of Economy, Trade and Industry (RIETI), Hitotsubashi University, and the University of Tokyo.

This paper is posted at ScholarlyCommons. https://repository.upenn.edu/prc_papers/111

For more information, please contact repository@pobox.upenn.edu. 


\title{
Retirement in Japan and the United States: Cross-national Comparisons using the Japanese Study of Aging and Retirement (JSTAR) and the U.S. Health and Retirement Study (HRS)
}

\begin{abstract}
Cross-national comparisons of data from developed countries offer useful insights into the retirement process and policy. Here we summarize findings for older persons age 50-70 using new microdata files collected by the Japanese Study of Aging and Retirement (JSTAR) project, and we compare these with results in the U.S. Health and Retirement Study (HRS). We examine the relative importance of health, wealth, family, and other factors in work and retirement at older ages cross-nationally. Though both countries have relatively high employment at older ages, the Japanese have longer life expectancy, higher levels of financial wealth, and a lower public pension eligibility age. Our analysis, the first to compare these two rich data sources, suggests two conclusions (subject to revision when data weights become available). First, older Americans differ in key ways from their Japanese counterparts, particularly along educational, health, and wealth dimensions. Second, in some cases, there is a distinctly different impact of these factors on labor force outcomes. Specifically, age, sex, education, and wealth influence behavior differently across the two countries, though being obese or having better mental acuity/financial literacy scores has no differential impact. Thus observed differences in work patterns between Americans and Japanese at older ages are attributable to some identifiable factors; moreover, the results can be used to project future responses to changes in education, age, health, and wealth in order to account for the large differences in older workers' work patterns at older ages in Japan and the US.
\end{abstract}

\section{Disciplines}

Economics

\section{Comments}

The authors thank Hidehiko Ichimura and Satoshi Shimizutani for their assistance in using the new Japanese Study of Aging and Retirement. Excellent programming assistance was provided by Yong Yu. The Japanese Study of Aging and Retirement (JSTAR) was conducted by the Research Institute of Economy, Trade and Industry (RIETI), Hitotsubashi University, and the University of Tokyo. 


\title{
Retirement in Japan and the United States: \\ Cross-national Comparisons using the Japanese Study of Aging and Retirement (JSTAR) and the U.S. Health and Retirement Study (HRS)
}

\author{
Olivia S. Mitchell and John W. R. Phillips
}

September 2013

\author{
PRC WP2013-05 \\ Pension Research Council Working Paper \\ Pension Research Council \\ The Wharton School, University of Pennsylvania \\ 3620 Locust Walk, 3000 SH-DH \\ Philadelphia, PA 19104-6302
}

Tel: 215.898.7620 Fax: 215.573.3418

Email:prc@wharton.upenn.edu

http://www.pensionresearchcouncil.org

This work was supported by a grant from the Social Security Administration through the Michigan Retirement Research Center (Grant \# 5 RRC08098401-04-00), funded as part of the Retirement Research Consortium. The findings and conclusions expressed are solely those of the author and do not represent the views of the Social Security Administration, any agency of the Federal government, or the Michigan Retirement Research Center. The authors also acknowledge support provided by the Pension Research Council and Boettner Center at the Wharton School of the University of Pennsylvania. The authors thank Hidehiko Ichimura and Satoshi Shimizutani for their assistance in using the new Japanese Study of Aging and Retirement. Excellent programming assistance was provided by Yong Yu. The Japanese Study of Aging and Retirement (JSTAR) was conducted by the Research Institute of Economy, Trade and Industry (RIETI), Hitotsubashi University, and the University of Tokyo.

All findings, interpretations, and conclusions of this paper represent the views of the authors and not those of the SSA, any agency of the Federal Government, the Wharton School, or the Pension Research Council. (C2013 Pension Research Council of the Wharton School of the University of Pennsylvania. All rights reserved. 


\title{
Retirement in Japan and the United States: \\ Cross-national Comparisons using the Japanese Study of Aging and Retirement (JSTAR) and the U.S. Health and Retirement Study (HRS)
}

\author{
Olivia S. Mitchell and John W. R. Phillips
}

\begin{abstract}
$\underline{\text { Abstract }}$
Cross-national comparisons of data from developed countries offer useful insights into the retirement process and policy. Here we summarize findings for older persons age 50-70 using new microdata files collected by the Japanese Study of Aging and Retirement (JSTAR) project, and we compare these with results in the U.S. Health and Retirement Study (HRS). We examine the relative importance of health, wealth, family, and other factors in work and retirement at older ages cross-nationally. Though both countries have relatively high employment at older ages, the Japanese have longer life expectancy, higher levels of financial wealth, and a lower public pension eligibility age. Our analysis, the first to compare these two rich data sources, suggests two conclusions (subject to revision when data weights become available). First, older Americans differ in key ways from their Japanese counterparts, particularly along educational, health, and wealth dimensions. Second, in some cases, there is a distinctly different impact of these factors on labor force outcomes. Specifically, age, sex, education, and wealth influence behavior differently across the two countries, though being obese or having better mental acuity/financial literacy scores has no differential impact. Thus observed differences in work patterns between Americans and Japanese at older ages are attributable to some identifiable factors; moreover, the results can be used to project future responses to changes in education, age, health, and wealth in order to account for the large differences in older workers' work patterns at older ages in Japan and the US.
\end{abstract}

\section{Olivia S. Mitchell}

The Wharton School

University of Pennsylvania

3000 Steinberg Hall-Dietrich Hall

3620 Locust Walk

Philadelphia, PA 19104

and NBER

mitchelo@wharton.upenn.edu

\section{John W.R. Phillips}

National Institute on Aging

Division of Behavioral and Social Research

31 Center Drive

MSC 2292

Bethesda, MD 20892

john.phillips@nih.gov 


\title{
Retirement in Japan and the United States: \\ Cross-national Comparisons using the Japanese Study of Aging and Retirement (JSTAR) and the U.S. Health and Retirement Study (HRS)
}

\author{
Olivia S. Mitchell and John W.R. Phillips
}

Cross-national comparisons of data from developed countries have provided many insights into how culture, institutions, and the socioeconomic/demographic composition of populations contribute to the retirement process and outcomes. In this paper, we use a new Japanese micro dataset from a survey similar to the US Health and Retirement Study (HRS), the Japanese Study of Aging and Retirement (JSTAR), to compare the characteristics of older workers and retirees in Japan and the United States. Specifically, we investigate how health, socioeconomic, and family factors relate to work and retirement for persons age 50-70 in Japan and the United States. Our analysis, the first to compare these two rich data sources, shows that Americans differ in key ways from their Japanese counterparts, particularly along educational, health, and wealth dimensions; moreover, there are distinctly different impacts of these factors on labor force outcomes.

International comparisons with harmonized data offer new perspectives on population aging, relative to single country studies. Examining differences in the distributions of population characteristics (i.e., age, education, health, family structure) across different institutional settings (i.e., social security or public health systems), analysts can consider how policies lead to outcomes of interest, such as eligibility for public benefits or retirement behavior (NRC, 2001). This has spurred the development of cross-nationally comparable survey data using the U.S. Health and Retirement Study as a model in countries around the world, including the English Longitudinal Study of Aging (ELSA) and the Survey of Health, Ageing, and Retirement in Europe (SHARE). Already these data investments have contributed to cross-national research on 
retirement and have helped analysts tackle difficult empirical challenges. For example, Rohwedder and Willis (2010) use the HRS, ELSA, and SHARE to examine the effect of early retirement on cognitive decline. They draw on variations in pension, tax, and disability policies across the countries that impact retirement in a way that is primarily unrelated to cognition to address the issue of endogenous retirement and conclude that early retirement appears to have a significant negative impact on cognitive ability. Other contributions to the retirement literature using these cross-nationally comparable data include, self-employment and retirement (Zissimopoulos et al., 2007), examining the incentives of disability programs (Börsch-Supan, 2007), and the impact of public pensions on household assets (Hurd et al., 2009).

Japan and the United States have differences that make comparisons of their retirement process potentially interesting. Older populations in both Japan and the United States have relatively large working populations at older ages compared to other developed countries, but many differences with regard to health, life expectancy, pensions, and demographics. In 2008, the labor force participation rates of 50-64 year olds in Japan and the US were $73.1 \%$ and $70.7 \%$, respectively, above the average of OECD and G20 countries $(63.3 \%)$ in that year (OECD 2011). Work between the ages of 65-69 in 2008, above the pension ages in most countries, is also high in these countries, particularly in Japan: $49.6 \%$ versus $35.6 \%$ in the US (OECD 2011). What characteristics explain both the relatively high labor force participation in these two countries as well as differences in rates across countries? Health, pensions, and demographics could provide some explanations.

The population in Japan is aging much faster than the United States due to lower fertility and higher life expectancy in Japan (Hurd and Yashiro, 1997). According to World Bank (2012) reports, Japanese life expectancy at birth in 2010 was 86.4 for women and 79.6 for men, versus 
80.7 and 75.9 for US women and men. In a life-cycle model, mortality risk will influence the retirement decision, so individual expectations about life expectancy could motivate shorter or longer working lives (Hurd et al., 2004). Other measures of health imply more mixed outcomes. For example, the likelihood of being overweight is significantly higher in the US population (prevalence of $3.5 \%$ in Japan versus $35.9 \%$ in US in 2010). While the incidence of smoking is higher in Japan; daily smoking patterns are less different, however (19.5\% of Japanese report smoking every day compared with $15 \%$ in the US; OECD 2005). A large body of research has shown that poor health leads to early retirement, so differences across countries in health conditions could describe some differences in work at older ages. Of interest are which conditions are differentially influential, and at what level of significance.

Both countries have a social security system (public pensions) and employer-sponsored pensions. The Japanese system has tiers: the first is the National Pension Program (NP) that pays a flat basic pension ( $¥ 792,100$ annually in 2008 , or about $\$ 10,000$ at 2012 exchange rates) at age 65 based on 40 years of contributions (OECD 2011). A minimum of 25 years of contributions are required to qualify and benefits are adjusted proportionately based on contribution period. An early pension is available at age 60 with at least 25 years of contributions and there are provisions for both spouses and survivors (SSA, 2011). The NP has no requirement to cease employment and there is no earnings test (SSA, 2011). The second tier consists of an earnings-related pension paid in addition to the NP benefit, called the Employees' Pension Insurance Program (EP). EP covers private sector workers excluding the self-employed and civil servants, though the latter group is covered under a different but similar scheme. Individuals qualify for benefits at age 60 with at least 25 years of coverage and receive benefits based on the insured's average monthly wage over the full career multiplied by a coefficient determined by 
the insured's date of birth multiplied by the number of months of coverage (SSA, 2011). While there is no requirement to stop working to receive benefits, there is an "earnings test" that reduces the pension if the total of the monthly pension and the earnings exceed a limit that varies based on the age of the worker - younger workers age 60-64 have a lower limit than workers aged 65-69 (SSA 2011). The NP and EP also have disability components that depend on meeting disability criteria (assessed with a disability requiring constant attendance or a degree of disability that severely restricts the person's ability to live independently) as well as a contribution requirement (paid contributions during $66.7 \%$ of the period from age 20 to two months before the month of the first medical exam), which pays a benefit that is more generous than standard retirement benefits (SSA, 2010). Nevertheless, research on disability awards in Japan shows that program participation is very low (3-4\% for men aged $50-54$ and $60-64$ in 2010) so the DI program has very limited impact on labor force participation (Oshio and Shimizutani, 2011). Employer-provided pensions represent the third tier; these plans cover about two-thirds of private sector EP participants (Oshio and Oishi, 2004). Employees can take their benefits as a lump-sum payment, an annuity, or both. An employer mandatory retirement age of 60 is not uncommon in Japan (Shimizutani, 2009), but employers often assist workers getting jobs at new employers or even changing status at the same firm (Clark and Ogawa, 1997; Oshio and Oishi, 2004). Recent changes in law require firms with a mandatory retirement age to provide employment opportunities for workers up to age 64 who wish to continue working and prohibit them from setting the mandatory age under age 60 .

The US Social Security system has some similarities to the Japanese system. The program pays full retirement benefits to covered workers at their full retirement age, which is age 66 for workers born in 1945, and gradually increases by birth cohort to age 67 (SSA 2012). 
There is also a single tier of benefits based on contributions over the working life that resembles the Japanese EP: American workers earn quarters of coverage (up to four each year) based on their contributions and must have 40 by their full retirement age to receive full benefits. Benefits are computed with the average indexed monthly earnings of a worker using a progressive formula. Workers can claim benefits as early as age 62 or delay until age 70 and benefits are actuarially modified accordingly (SSA, 2012). The US Social Security program also provides spousal, widow, and disability components. In the case of disability benefits, applicants must meet a work requirement (including recent work activity) and have a condition that limits work and will last for a significant period of time (SSA, 2012). While research suggests the Japanese disability system is not a significant pathway out of the labor force, the fraction of Americans receiving disability benefits has grown substantially due to changes in screening, an increase in the DI replacement rate, and the growth of female labor force participation (Autor and Duggan, 2006). Nevertheless, cross-national comparisons suggest that US DI enrollment rates are below average compared to many European countries (Börsch-Supan 2007). As in Japan, US employer pensions provide another layer of retirement assets. More than $60 \%$ of full-time US workers participated in employer pensions (both defined benefit and defined contribution) in 2009 and participation among civil servants was even higher (Anguelov et al., 2012), for a coverage rate comparable to that of Japan.

Many analysts have explored how these retirement systems influence retirement. One finding in the retirement literature is that social security pensions do shape older workers' labor supply fairly strongly. In the US, for instance, the tendency for workers to quit work at age 62 materialized only after the Social Security early eligibility age was introduced (Burtless and Moffitt, 1984). Studies examining the effect of the magnitude of benefits on labor supply 
generally find significant but small effects on retirement timing (c.f. Fields and Mitchell, 1984; Coile and Gruber, 2004; and Gustman and Steinmeier, 2009). Employer pensions have also been shown to encourage earlier retirement due to rules offering strong financial incentives to leave the job early (c.f. Mitchell and Fields 1982; Stock and Wise 1990). For Japan, analysts have also concluded that the social security system shapes workers' incentives (Oshio, et al. 2011). That is, labor supply at older ages is reduced due to the availability of benefits at age 60 and negative benefit accruals after age 59 (Oshio and Oishi, 2004), as well as work penalties between ages 6064 in the pension system (Naohiro and Oshio, 1999). Seike (1997) finds that a substantial number of workers quit when the earnings test becomes binding, just as in the US (Friedberg, 1998). The important cross-national team led by Gruber and Wise (1999) has examined the impact of public pensions/social security systems on the labor force participation of older populations in Belgium, Canada, France, Germany, Italy, Japan, Netherlands, Spain, Sweden, the United Kingdom, and the United States. That cross-country analysis shows that program provisions can impose large financial penalties on labor earnings after a program's early retirement age. The team introduced the concept of "unused labor capacity" across the countries studied, showing how each country's social security rules affected older workers' market participation. Interestingly, of the 11 countries analyzed, unused labor capacity in Japan and the United States was relatively small. Thus, while the public pension systems in these countries do discourage work at older ages, their influence is relatively small compared to most other developed countries.

The Health and Retirement Study (HRS) has provided rich longitudinal data on the health, wealth, and family circumstances of older Americans; it has also served as a model for data collections in other countries. Yet it has been difficult to make Japan/US comparisons due to 
the lack of a harmonized publicly-available microdataset of the older Japanese population. Thus, most previous research on the Japanese experience uses cross-sectional data with limited information on health, wealth, and family characteristics. Additionally, though some researchers have examined retirement patterns in both countries, few have compared the socioeconomic, health, and family characteristics of older workers in these two countries, due mainly to the lack of Japanese data. One exception is the work of Raymo et al. (2004), which used longitudinal Japanese microdata from the 1990's (National Survey of the Japanese Elderly) to measure labor force participation responses to work history and family characteristics. That work concluded that occupational history and family structure significantly affected work at older ages, and differentially for men and women. The impacts of both marriage and co-residing children on the wage employment of women was similar to results from US studies (Pienta et al., 1994). These analyses had access to very limited measures of health, and no information on wealth.

In what follows, we use the JSTAR and the HRS to compare characteristics of older workers and retirees in Japan and the United States. Accordingly, we are able to use more contemporary data than has been available in the past, as well as a richer set of explanatory and outcome variables. In particular, our access to measures of cognitive ability and hours of work add to previous studies to illustrate how these additional factors differentially impact work and retirement in these two nations. 


\section{Data}

The dataset on older Americans is derived from the Health and Retirement Study. ${ }^{1}$ Since 1992, this survey has been the pre-eminent source of information on older Americans about work and retirement, health and wealth, economic circumstances, and family. The sample is constructed to be nationally representative of the population over age 50 and is interviewed every other year. For the present purposes, we use HRS data mainly from the 2006 wave to be comparable to the Japanese survey data collected in $2007 .^{2}$ The HRS features rich measures of health (including subjective life expectancy and Body Mass Index or BMI), cognition, financial capability, demographics and family characteristics, financial wealth, and labor force activity. ${ }^{3}$

The Japanese data we use are taken from in the newly released Japanese Study of Aging and Retirement (JSTAR; Ichimura et al., 2009). This study was conducted in 2007, and it included around 4,200 respondents age 50-75 from five cities/wards across Japan: Takikawa, Sendai, Adachi (a ward within Tokyo), Kanazawa, and Shirakawa. ${ }^{4}$ In contrast to the conventional approach of conducting nationally representative random sampling, the JSTAR study used stratified random sampling within each municipality. In order to generalize results to the national level, one would then require special weights, which have not yet been made available. Accordingly, all results reported below are tentative and will be re-run when the weights become available.

The JSTAR instrument was heavily influenced by the HRS, so many of the concepts measured (e.g., health, wealth, cognition, etc.) are similar to those in the HRS. Item concordance

\footnotetext{
${ }^{1}$ See http://hrsonline.isr.umich.edu/index.php.

${ }^{2}$ Two financial literacy variables are from the $2006 \mathrm{HRS}$, as they were unavailable in 2008.

${ }^{3}$ The RAND Corporation produces a user-friendly version of the HRS (described on the HRS website) with welldocumented and cleaned versions of variables we utilize in this study to aid future replication of results.

${ }^{4}$ In 2009 a second wave of the JSTAR added more municipalities, but that dataset is currently not available for public use.
} 
between JSTAR and HRS can be quickly determined using the RAND Survey Metadata Repository. ${ }^{5}$ The JSTAR does not link to administrative data resources covering social security earnings and benefits data matched to respondents as in the HRS, so this limits our purview to questions asked in the 2007 cross-section. We also cannot calculate expected social security or employer pension wealth in this analysis, because of the challenges of identifying public and private pension eligibility using survey data in the 2007 JSTAR wave. In future research, we hope to use the 2009 JSTAR survey to improve our ability to determine plan/program eligibility and estimate these values.

\section{Methodology}

The empirical work that follows analyzes the 50-70 year olds from both datasets; as noted above, all results are preliminary as the data are unweighted. ${ }^{6}$ In what follows, we first report descriptive statistics for the key outcome variables of most interest in the HRS and JSTAR datasets, comparing various moments of the two surveys. In the next section we report regression estimates for a core set of control variables, and subsequently we add an additional set of health and financial literacy controls. Extensive additional descriptive statistics appear in the Appendices.

\section{Descriptive Statistics}

Five key outcomes are of key interest for our comparative analysis using the Japanese and US samples. Specifically, we examine the probabilities of not working, being retired, and

\footnotetext{
${ }^{5}$ See https://mmicdata.rand.org/meta/

${ }^{6}$ Accordingly, these findings should not be generalized to the respective nations for this age bracket of respondents until the analysis can be confirmed with the weighted data. When the JSTAR weights are received we will replicate all analysis reported here.
} 
receiving a social security (government) benefit for all respondents, and for those who indicate they are working, we separately analyze the number of work hours per week and the age they expect to receive social security benefits. Table 1 provides means, medians, and other moments for these outcomes in the two datasets.

\section{Table 1 here}

Results for the 50-70 age group show that $60 \%$ of the HRS respondents say they are not working, while only one-third (34\%) of the Japanese do so. ${ }^{7}$ This conforms to our expectation that labor force attachment in Japan would be higher at older ages than for the US sample. But interestingly, in the US, only $39 \%$ of this population considers itself retired, and only $8 \%$ of the Japanese do. Clearly not working and being retired mean different things to this age group, but the fact that only $8 \%$ of the Japanese in this age group deem themselves 'retired' versus the $34 \%$ rate of non-work suggests that the Japanese concept of "retirement" measures something rather different than in the US.

Table 1 also shows that rates of receipt of government pensions differ in the two nations: for the US sample, 52\% of the 50-70 age group reports receiving Social Security benefits, whereas in Japan the proportion is lower, at $44 \%$. Focusing next on the subset that is currently working, we see that average weekly work hours are quite similar across the US and Japan. The last row of Table 1 shows that, among employed older men, Americans anticipate claiming benefits at age 64.8, whereas the Japanese intend to claim around half a year earlier, at 63.9. Overall, the findings suggest that older Japanese are more likely to work to later ages and few consider themselves retired, but rates of government pension receipt are more comparable in

\footnotetext{
${ }^{7}$ This accords relatively well with national data from the US reported at http://www.bls.gov/spotlight/2008/older_workers/ and Japan reported at http://www.stat.go.jp/english/data/roudou/154.htm\#TAB
} 
both countries. Moreover, those who remain employed at older ages work about the same number of hours and have roughly similar claiming age expectations.

Table 2 describes several key demographic and economic factors that we will use as controls in the multivariate analysis to come. Variable definitions appear beneath the table. The two groups are of similar age, 62 in the HRS, and 61 in JSTAR. The fraction male is lower in the HRS at $40 \%$, versus $51 \%$ in the JSTAR; whether this difference persists when the data are weighted, or perhaps because of differential mortality patterns across the two countries, cannot be determined at present. Educational patterns across the countries are also of interest. Just under a quarter of the Americans currently age 50-70 were high school dropouts, while just over a quarter of the Japanese had the same low level of educational attainment. At the top of the educational range, some $10 \%$ of the HRS group had completed college or gone beyond, with only $1 \%$ of the Japanese reporting that level of educational attainment.

\section{Table 2 here}

Turning to family status, older Japanese are much more likely to be married $-82 \%$ versus $69 \%$ in the US - and have fewer living children -1.95 versus 3.16 in the US. This is the result of much-lower fertility rates, which have characterized Japan for decades. Nevertheless, the traditional multi-generational family structure continues to be prevalent in Japan, with $48 \%$ of the older population living with own children in their households, versus $25 \%$ in the US for the same age range. This is despite the fact that in the US, self-reported health problems are much more widespread, with $27 \%$ of the Americans indicating that their health was worse than average; conversely, only $16 \%$ of their Japanese counterparts indicate that they believe themselves to be in below-average health. These differential health assessments are also observed in the very high probabilities of living longer than the population mortality tables 
would indicate: two-thirds of the Japanese have an optimistic assessment of the chances of living to age 75 , compared to the life table for their country versus only $41 \%$ of Americans. Total years in the labor force average about 33 for the US subsample, versus about 30 for the JSTAR sample. ${ }^{8}$

Financial wealth measures in the two datasets are computed as the sum of cash, stocks and bonds. The US mean (median) for this variable is around $\$ 100,000(\$ 5,000)$; in JSTAR the mean (median) equals $\$ 193,000$ ( $\$ 41,000)$. Both are suggestive of skewness in the distribution of net wealth, confirmed by the rows reporting the percentage in four wealth brackets. In Japan, however, the percentage of respondents with negative financial wealth (in debt) is only $3 \%$, whereas it is $21 \%$ of the US comparable population. The fraction with wealth over $\$ 100,000$ is much closer, $20 \%$ in the US and $18 \%$ in Japan. But the JSTAR maximum wealth reported ( $\$ 25$ million) greatly exceeds that of the HRS (\$16.8 million), and in the HRS the minimum reported wealth is $-\$ 1.5$ million, meaning the household is deeply in debt. In Japan the least wealthy household in this age bracket is relatively better off, with only $-\$ 9,000$ in debt (all monetary values are in US 2006 dollars). Another point worth noting is the marked reluctance of Japanese respondents to report financial wealth values; only $55 \%$ of the JSTAR sample was willing to reveal these values. In the case of the HRS, more respondents give answers and the RAND dataset imputes missing wealth values (St. Clair et al., 2011). Of course, all results are tentative pending release of the JSTAR weights.

Some of the analysis below focuses on outcomes for older workers separately, so Table 3 is informative on this subset (which can be compared to Table 2). Not surprisingly, the average age of workers is lower in both surveys, but in the US 50-70 age group, the employed subset is three years younger overall, while in Japan the age difference is just under 1.5 years. The US

\footnotetext{
${ }^{8}$ Again, numbers may change with weighting, so results are preliminary.
} 
median is younger as well, at 58, compared to the Japanese median of 59. Workers are more likely to be male, married, and better educated, in both surveys, than the population as a whole. In the US, older workers have somewhat fewer living children than overall (3 versus 3.2), whereas the Japanese workers have approximately the same number of children. What is notable, however, is that in both nations, older workers are more likely to share their homes with children.

Table 3 here

Turning to other aspects of the older workforce, we see in Table 3 the US/Japan gap narrows in terms of the fraction reporting having below average health. Only $16 \%$ of US older workers state they are in worse than average health, versus $11 \%$ of the Japanese; both rates are below the respective $27 \%$ and $16 \%$ reported in the larger population. Surprisingly, the better health of the workers does not translate into more optimistic survival probabilities; in both cases about $42 \%$ of the Americans and $66 \%$ of the Japanese believe they will live to age 75 . Median wealth for workers is about the same as for the entire population, though for US workers the mean is below that of the entire age group. Moreover, the fraction in debt in the US, at $24 \%$, is again far higher than in Japan, with only 3\% in that grouping; conversely, more HRS respondents $(11 \%)$ have over $\$ 200,000$ in financial wealth than do their Japanese counterparts $(7 \%){ }^{9}$

\section{Multivariate Models}

Next we turn to multivariate regression models to explore how key demographic and economic variables are linked to key retirement outcomes, holding constant other factors. In this

\footnotetext{
${ }^{9}$ These values will be revised with weighted data, as appropriate.
} 
section $_{2}$ we analyze the first four outcomes described above: for the entire sample, the probability of not working, self-reporting retired, and receiving social security benefits; and for workers, the number of work hours per week. Our approach is to pool the HRS and JSTAR datasets and regress the key outcomes on two sets of controls. ${ }^{10}$ The first set we refer to as the 'core' variables is listed in Tables 3 and 4: they include age, sex, education, marital and family status, health and life expectancy, years of labor market experience, and financial wealth. Subsequently, we again analyze the four outcomes of interest but add to the core controls an additional set of factors informative about respondents' physical and mental well-being. Four measures are included in this new set: an indicator of having a Body Mass Index greater to or equal to 25 (indicative of overweight); a word recall score (out of 10; indicative of memory); a Serial 7's score (maximum 5; indicative of mental acuity); and a financial literacy score (out of 2) that reflects whether the respondent understands the concept of compound interest and inflation. ${ }^{11}$

The approach we adopt generates coefficient estimates for the control variables in the HRS along with an estimate of the differential impact of each variable in the JSTAR dataset. In an OLS regression setting, we have the following:

$$
\mathrm{y}=\underline{\beta}^{*} * \underline{\mathrm{X}}+\underline{\mathrm{J}}^{*} * \underline{\mathrm{X}}+\varepsilon
$$

Here $\underline{\beta}$ is a vector of coefficient estimates on the vector of control variables $\underline{X}$; these should be interpreted as effects in the HRS dataset. The $\underline{\mathrm{J}}$ ' interaction terms refer to the differential impacts of each $\mathrm{X}$ variable in the JSTAR sample. Thus, the full effect of one $\mathrm{X}$ variable in the Japanese dataset would be the sum of that variable's $\beta$ ' $+\underline{\mathrm{J}}$ ' term. A similar format is used for Logit models (employed in the case of $(0,1)$ dependent variables; in this latter case, we mainly

\footnotetext{
${ }^{10}$ Our approach is similar to that of Börsch-Supan (2007) who explored the factors associated with disability insurance enrollment across several European surveys as well as the HRS.

${ }^{11}$ These two questions are a subset of the larger group developed by Lusardi and Mitchell $(2007 ; 2011)$ and implemented in a wide range of surveys around the world.
} 
refer to estimated marginal effects rather than the Logit coefficients (which are difficult to interpret on their own). In each case, the stars refer to the statistical significance of the coefficient estimate reported in the table. Missing data dummies are included for any explanatory variable with a missing value for that observation.

Core Controls. Results for the core set of controls are provided in Tables 4-7, one per outcome variable of interest. Table 4, for instance focuses on the determinants of the probability of not working; both Logit estimates and marginal effects are provided. For the HRS population, results appear in the leftmost two columns. Here we see that Americans age 50-70 are more likely to report not working when they are older, male, have below-average health, and are wealthier. Conversely, those with at least some college education (and especially post-graduate education) are less likely to say they do not work, along with those having more children, more children living at home, and having more labor market experience. People anticipating living longer also are less likely to have left work. The differential impact of all variables in the Japanese context can be judged by the significant coefficients in the right-most panel. Overall, the Japanese are more likely to not work, as indicated by the coefficient on $\mathrm{J}^{*}$ intercept; however, this is significant only at the $10 \%$ level. The impact of age is negative, as is being male: this means that in JSTAR, older persons and men are more likely to work than their counterparts in the HRS. Education has some differential effect across the two surveys: persons having a high school degree or some college are more likely to not work. Having more children is more strongly associated with work in Japan than in the US, though co-residence has no differential effect. The only other differential effect for the JSTAR estimates is a positive significant relationship 
between longer labor market tenure and non-work at older ages. This is likely a reflection of the impact of the mandatory retirement age in Japan, which would not apply in the US context.

\section{Table 4 here}

In Table 5, we summarize how the same core controls are associated with the probability of self-reporting being retired. As before, being older and being male in the HRS is positively associated with retirement status, though now educational attainment is only very weakly linked to that outcome. Those who are married are less likely to say they are retired, as are those with children living at home, those expecting to live longer, and those with more labor force attachment. Wealth is again strongly and positively associated with retirement, as is the poor health indicator. The $\mathrm{J} *$ intercept term is negative, significant, and quantitatively quite large, corroborating our earlier finding that Japanese are less likely to report themselves as retired. Different from Table 4, older Japanese and men are more prone to say they are retired compared to the HRS respondents, and having some college is again associated with retirement (significant at the $10 \%$ level). Having more children or co-resident children have no differential effects on retirement in the JSTAR as compared to the HRS. Table 5 also indicates that those with belowaverage health are less likely to say they are retired in Japan, compared to the US, while again there is positive significance differential between longer labor market tenure and retirement in Japan.

\section{Table 5 here}

In Table 6, we turn to an examination of the factors associated with the probability of social security benefit receipt. Since this dependent variable is another way to measure older persons' work status, it is not surprising that similar results obtain to those already reported. Once again, in the HRS, older and male respondents have higher probabilities of benefit receipt, 
and having more education is negatively associated with having claimed benefits. As in Table 5, being married is negatively associated with benefit receipt, as does the impact of having children at home; longevity expectations are not significant, but those with longer labor force attachments have lower rates of benefit receipt. Most of the wealth controls are not statistically significant, but the one that is suggests that people with medium financial wealth $(\$ 100-200,000)$ are less likely to have claimed social security benefits. Turning to the differential effects in JSTAR, we see that the intercept and the age terms are not significant, in contrast to the two prior tables. Men and married persons are much less likely to have claimed benefits, and those with some college are more prone to do so. Having more children is not significant as in Table 5, though persons with more children at home are more likely to receive benefits. Table 6 also indicates that those with below-average health are far less likely to say they receive benefits in Japan compared to the US, and there is again a positive significance differential between longer labor market tenure and benefit receipt in Japan.

\section{Table 6 here}

Table 7 focuses on just the subset of workers in the two datasets, to explore what factors are associated with more weekly hours of work. It will be recalled that the US workers put in $60 \%$ more hours than the average Japanese worker per week, a marked differential. Interestingly, relatively few factors are significantly associated with the differential. Older persons work fewer hours, with the effect of age being even more negative in Japan. But the magnitude of the age differential is small, around half an hour per week. Both in the US and Japan, men work more hours with the advantage to the Japanese, holding other things constant. Respondents with only a high school education work less in Japan, and married Japanese work about two hours less per week. Having higher wealth levels is strongly associated with fewer work hours in Japan, but not 
significantly so in the US. It is interesting that the core set of variables accounts for only about $41 \%$ of the variance in work hours in this model, leaving room for exploring additional factors that contribute to the striking differences in work hours across countries.

Table 7 here

Additional Controls. Next, we present a series of models where the core set of controls has been extended to include an indicator for BMI $\geq 25$; a word recall score; the Serial 7's score; and a financial literacy score. Tables 8 and 9 summarize the distributions of these variables for all respondents as well as only the working subset. Among the entire population (Table 8), we find that $74 \%$ of Americans in the $50-70$ range would be classified as obese or heavier by the BMI index, in contrast with only $25 \%$ of the JSTAR respondents. Older Americans score better on word recall, 5.8 versus 5.2, but worse on the Serial 7's test (3.6 versus 4.2). Financial literacy is also lower for the HRS than for JSTAR respondents, at 1.1 versus 1.4. Among workers (Table 9), BMI results are similar, though workers in the US score markedly better on the word recall and Serial 7's tests. Interestingly, workers in Japan scores are comparable to those in the larger population on those items. For financial literacy, the Japanese score about 3 of a question better than the HRS respondents, both in the population and the subset of workers alone.

\section{Tables 8 and 9 here}

Results for the probability of not working in HRS and JSTAR are reported in Table 10, which replicates Table 4 with the additional controls. At the outset, we note that the overall percent of variance explained is unchanged; accordingly, we would not anticipate many changes in the coefficient estimates. Indeed this is what we find. Signs and significance levels are qualitatively similar to results in Table 4 , though the $\mathrm{J} *$ intercept term is attenuated, indicating 
that the new variables do provide some useful additional information. Among the new variables, the BMI score is not significant in either survey, though people scoring well on both the word recall and Serial 7's test are more likely to be working; the effects are similar in the US and Japan. Financial literacy is not associated with work status in the US, whereas in the JSTAR there is a significant increase in non-work associated with a higher score.

\section{Table 10 here}

Table 11 turns to the factors associated with self-reporting being retired. Again the Rsquared is unchanged, though some of the new variables have significant coefficients without much change in the coefficient estimates for the core variables. Americans with BMI scores of $25+$ are more likely to report themselves as retired, and there is no differential Japanese effect. All three of the cognitive/literacy variables have negative signs, though only the financial literacy score has a significant coefficient in the HRS sample. Interestingly, among the Japanese, those who are more financially literate have a higher rather than a lower probability of indicating they are retired.

\section{Table 11 here}

A comparison of Tables 6 and 12 reveals a very small (1\%) change in the R-squared, and very few other important changes in the coefficient estimates on the core variables. Americans as well as Japanese with higher word scores and Serial 7's scores are less likely to have claimed social security benefits, though there is no evidence that more financially literate individuals delay claiming. ${ }^{12}$

\section{Table 12 here}

\footnotetext{
${ }^{12}$ Though others have shown that more financially literate Americans understand annuities better (Brown et al. 2012).
} 
In Table 13, we provide results from the work hours model in Table 7 with the extended set of controls. Again, adding the additional variables does not increase the variance explained by the model, while coefficient estimates and significance levels are quite comparable. Being overweight in the US is associated with one more hour of work per week, while none of the additional variables is differentially significant for the JSTAR subset.

Table 13 here

Age Expects to Receive Social Security Benefits. Two additional tables are offered to illuminate which factors are associated with the expected age of claiming social security benefits for workers in the two samples. Table 14 reports coefficient estimates for the core controls alone, while Table 15 includes the additional overweight indicators and test scores. In both cases, the R-squares are lower (8-9\%) versus $16 \%$ in the work hours models, but more factors are statistically significantly different from zero. Here, older workers expect to claim later, but the age impact for the Japanese sample is slightly lower. Whereas, in the US having more education is associated with later claiming ages, in Japan having a high school degree or some college lowers the expected retirement age (versus being high school dropout). Wealthier workers anticipate claiming earlier, with the effect being similar across both datasets. Including the additional four factors in Table 15 has relatively little effect on the coefficients of core variables as well as the $J *$ interactions. Interestingly, people with higher word, Serial 7, and financial literacy scores are more likely to claim later, though the estimated coefficients indicate small measured effects. The Japanese behave fairly similarly.

Tables 14 and 15 here 


\section{Summary and Discussion}

Our interim set of results for the Japanese and American population age 50-70 has provided numerous interesting insights. ${ }^{13}$ More of the HRS respondents $(60 \%)$ are not working, compared to only one-third (34\%) of the Japanese, consistent with our priors that labor force attachment is higher at older ages in Japan than in the US. And more of the HRS respondents $(52 \%)$ indicate they receive government-provided pension benefits compared to the JSTAR group (44\%). By contrast, however, only 39\% of the HRS age group considers itself retired, and only $8 \%$ of the Japanese do. Evidently, not working, being retired, and having claimed benefits mean very different things, both within and across countries. If we focus on workers only, individuals in the two countries are more similar, with both averaging around 40 hours of work per week. And the HRS workers anticipate claiming benefits only about half a year later than their JSTAR counterparts.

Some of these differences are attributable to differences in demographic and economic factors, while others are due to differences in responses to the factors themselves. Our results overall suggest that age differences across the sample are virtually nil, by design - we only included persons age 50-70. In the HRS, people are less likely to be male and married than in the JSTAR, whereas, Americans have more living children and are more likely to be well-educated than the Japanese in this age bracket. Only one-quarter of the HRS has own children co-residing with them, whereas in Japan the proportion is still $45 \%$.

Financial wealth measures in the two datasets are very skewed, but reported wealth in the JSTAR is more compressed than in the HRS. Two-fifths of the older US population reported negative assets, whereas, in Japan, however, the percentage of respondents with negative

\footnotetext{
${ }^{13}$ All results are tentative; new results will be provided when weights have been made available.
} 
financial wealth was $3 \%$. The fraction with wealth over $\$ 100,000$ was closer, $21 \%$ in the US and $18 \%$ in Japan. These statistics will need to be verified with weighted data.

One of the most striking and consistent differences between older persons across countries has to do with the prevalence of bad health. Thus, over a quarter of the HRS respondents report being in worse health than average, versus only $16 \%$ of the JSTAR sample. Additionally, three-quarters of the Americans are obese (or heavier), versus one-quarter of the Japanese. Older Americans do fare better on the word recall test, but they score worse on the Serial 7's and financial literacy tests. Such differences in health translate into very different selfassessed probabilities of living a long time. Only two-fifths of older Americans have an optimistic assessment of the chances of living to age 75 (vis-à-vis a life table for their country) whereas, two-thirds of the Japanese are optimistic in this dimension. Many of these patterns persist for the subset of working individuals.

Our multivariate models allowed us to test whether the impacts of these variables differs significantly across the two datasets, after controlling on differences in the explanatory variables. To summarize our findings, in the HRS, age is generally significant in boosting the chances of not working, being retired, receiving social security benefits, and working more weekly hours. In the JSTAR sample, age plays a confounding role: older persons are less likely to say they are not working, more likely to claim they are retired, and less likely to have social security benefits than Americans. Conditional on working, age reduces hours by more than in the HRS. Men in the HRS are more likely to say they are not working, be retired, and have claimed benefits; conditional on working, they work more hours. Again, the interaction effects for JSTAR suggest that Japanese men are much less likely to report not working or receiving benefits; on the other hand they are much more likely to describe themselves as retired. Education has similarly 
confounding effects: in the US, the more educated have a higher probability of working (and work more hours), and a lower chance of having claimed benefits. The picture is very different for the Japanese, where those with a middling amount of education are more likely to not work, say they are retired, and say they receive social security benefits. These findings remain to be confirmed with weighted data, of course.

The impact of health variables on work and retirement outcomes are remarkably similar overall, across the two samples examined. In the US, having below-average health is strongly associated with not working, being retired, and claiming benefits. Poor health has no differential affect on the Japanese respondents' chances of working, though it does greatly reduce the chance that someone calls himself retired or receives social security benefits. In the extended models, being overweight is positively associated with being retired for Americans and there is no differential impact among the Japanese. Those with higher levels of mental acuity and financial literacy are more connected to the labor market across the board in both the US and Japan. Finally, among workers, there are also relatively few factors that differentiate hours worked and their expected benefit claiming age: in both countries, wealthier individuals are likely to work fewer weekly hours, but there is no substantive differential effect across the samples.

In results we do not detail here but provide in Appendices 1-3, we offer additional comparative information on 50-70 year olds in each dataset for narrow age groups. Results are generally reinforcing of findings reported above.

\section{Tentative Conclusions and Future work}

Two conclusions may be drawn, subject to revision when the needed weights are provided. First, Americans age 50-70 do differ in key ways from their Japanese counterparts, 
particularly along educational, health, and wealth dimensions. Second, in some cases there is a distinctly different impact of these factors on labor force outcomes. Specifically, age, sex, education, and wealth influence behavior differently across the two countries, though being obese or having better mental acuity/financial literacy scores has no differential impact. Accordingly, observed differences in work patterns between Americans and Japanese at older ages can be attributable to a key subset of identifiable factors; moreover, the results can potentially be used to project future responses to changes in education, age, health, and wealth.

This follow-on effort must, however, await a revision of all reported statistics using weights when they are received from the JSTAR project. Using these estimated parameters, we will then examine how outcomes might differ if key factors such as health and life expectancy were to become more equal in Japan and the U.S. This will allow us to determine, to the extent possible, which particular values of economic and demographic factors might continue to stand out as key in explaining the large differences in older workers' work patterns at older ages within the HRS and JSTAR. 


\section{References}

Anguelov, C. E., H. M. Iams, and P. J. Purcell (2012), "Shifting Income Sources of the Aged", Social Security Bulletin 72(3): 59-68.

Autor, D. H., and M. G. Duggan (2006), "The Growth in the Social Security Disability Rolls: A Fiscal Crisis Unfolding." Journal of Economic Perspectives 20(3): 71-96.

Börsch-Supan, A. (2007), "Work Disability, Health, and Incentive Effects,” MEA Working Paper 135-2007, Mannheim Research Institute for the Economics of Aging, Mannheim University, Germany.

Brown, J. R., A. Kapteyn, E. Luttmer, and O.S. Mitchell. 2011. "Do Consumers Know How to Value Annuities? Complexity as a Barrier to Annuitization." Pension Research Council Working Paper. Wharton School.

Burtless, G. and R. Moffitt (1984), "The Effect of Social Security Benefits on the Labor Supply of the Aged", in H. Aaron and G. Burtless (Eds.) Retirement and Economic Behavior Washington, DC: Brookings Institution: 135-75.

Coile, C. and J. Gruber (2004) "The Effect of Social Security on Retirement in the United States," in J. Gruber and D. A. Wise, eds., Social Security Programs and Retirement around the World: Micro-Estimation. Chicago: The University of Chicago Press: 691729.

Clark, R. and N. Ogawa (1997). "Transitions from Career Jobs to Retirement in Japan," Industrial Relations 36(2): 255-270.

Fields, G. and O. S. Mitchell (1984). Retirement, Pensions, and Social Security. Cambridge, MA: MIT Press.

Friedberg, Leora (1998), “The Social Security Earnings Test and Labor Supply of Older Men”, in J. M. Poterba (Ed.) Tax Policy and the Economy, 12. Cambridge, MA: MIT Press: 121-150.

Gruber, J. and D. A. Wise (1999), Social Security and Retirement around the World. Chicago, IL: University of Chicago Press.

Gustman, A. and T. L. Steinmeier (2009), "How Changes in Social Security Affect Recent Retirement Trends." Research on Aging 31(2): 261-290.

Ichimura, H., H. Hashimoto, and S. Shimizutani (2009). Japanese Study of Aging and Retirement: JSTAR First Results 2009. Tokyo, Japan: Research Institute of Economy, Trade, and Industry. 
Hurd, M., and N. Yashiro. (1997). The Economic Effects of Aging in the United States and Japan. Chicago, IL: University of Chicago Press.

Hurd, M. D., P. C. Michaud and S. Rohwedder (2009). "The Displacement Effect of Public Pensions on the Accumulation of Financial Assets." Michigan Retirement Research Center Working Paper 2009-212, September. Ann Arbor, MI: MRRC.

Hurd, M. D., J. P. Smith and J. M. Zissimopoulos (2004). "The Effects Of Subjective Survival On Retirement And Social Security Claiming." Journal of Applied Econometrics 19(6S): 761-775.

JSTAR datasets. Research Institute of Economy, Trade and Industry (RIETI), Hitotsubashi University, and the University of Tokyo, distributed by RIETI in Tokyo, Japan.

Lusardi, A. and O. S. Mitchell. (2007). "Baby Boomer Retirement Security: The Roles of Planning, Financial Literacy, and Housing Wealth.” Journal of Monetary Economics. 54(1) January: 205-224.

Lusardi, A. and O.S. Mitchell. (2011). "Financial Literacy and Retirement Planning in the United States." Journal of Pension Economics and Finance, October: 509-525

Mitchell, O. S., and G. S. Fields (1982). "The Effects of Pensions and Earnings on Retirement." in Ronald Ehrenberg (ed.) Research in Labor Economics Vol. 5. Greenwich, CT: JAI Press: $115-155$.

National Research Council. (2001). Preparing for an Aging World: The Case for CrossNational Research. Washington, DC: National Academy Press.

OECD. (2011). Pensions at a Glance 2011: Retirement Income Systems in OECD and G20 Countries. OECD Publishing. http://dx.doi.org/10.1787/pension_glance-2011-en.

OECD. (2012). OECD Health Data 2012: How Does Japan Compare? http://www.oecd.org/els/healthpoliciesanddata/BriefingNoteJAPAN2012.pdf

Oshio, T. and A. S. Oishi (2004). "Social Security and Retirement in Japan: An Evaluation Using Micro-Data." in J. Gruber and D. A. Wise (Eds.). Social Security Programs and Retirement around the World: Micro-Estimation. Chicago, IL: University of Chicago Press: 399-460.

Oshio, T., A. Oishi and S. Shimizutani (2011). "Social Security Reforms and Labor Force Participation of the Elderly in Japan." Japanese Economic Review 62(2): 248-271.

Oshio, T. and S. Shimizutani (2011). "Disability Pension Program and Labor Force Participation in Japan: A Historical Perspective." National Bureau of Economic Research Working Paper 17052, May. Cambridge, MA: NBER. 
Pienta, A. M., Burr, J. A., and Mutchler, J. E. (1994), "Women's Labor Force Participation in Later Life: The Effects of Early Work and Family Experiences." Journal of Gerontology: Social Sciences 49B: S231-S239.

Raymo, J. M., J. Liang, H. Sugisawa, E. Kobayashi, and Y. Sugihara (2004). "Work at Older Ages in Japan: Variation by Gender and Employment Status." Journal of Gerontology, 59B(3): S154-S163.

Rohwedder, S. and R. Willis (2010). "Mental Retirement." Journal of Economic Perspectives 24(1): 119-138.

Seike, A. (1997), "Labor Market Implications of Social Security: Company Pension Plans, Public Pensions, and Retirement Behavior of the Elderly in Japan." in M. Hurd and N. Yashiro (Eds.) The Economic Effects of Aging in the United States and Japan. Chicago: University of Chicago Press: 295-315.

Shimizutani, S. (2009b). "A New Anatomy of the Retirement Process in Japan." Center for Intergenerational Studies, Institute of Economic Research, Hitotsubashi University PIE/CIS Discussion Paper 458. http://hermes-ir.lib.hitu.ac.jp/rs/bitstream/10086/17692/1/pie_dp458.pdf, October.

Shimizutani, S. and T. Oshio (2009a). "New Evidence on Initial Transition from Career Job to Retirement in Japan." Project on Intergenerational Equity and Center for Intergenerational Studies (CIS) Discussion Paper 430. Tokyo, Japan: Institute of Economic Research, Hitotsubashi University.

Social Security Administration (2011). Social Security Programs Throughout the World: Asia and the Pacific, 2010. SSA Publication No. 13-11802 (p. 99-106). Washington, DC: US Social Security Administration.

Social Security Administration (2012). Annual Statistical Supplement, 201. Washington, DC: US Social Security Administration: 9-18.

St.Clair, P., D. Bugliari, N. Campbell, S. Chien, O. Hayden, M. Hurd, R. Main, A. Miu, M. Moldoff, C. Panis, P. Pantoja, A. Rastegar, S. Rohwedder, M. Oshiro, J. Zissimopoulos. (2011). RAND HRS Data Documentation, Version L. November. http://hrsonline.isr.umich.edu/modules/meta/rand/randhrsl/randhrsL.pdf

Stock, J. H. and D. A. Wise (1990) "Pensions, the Option Value of Work, and Retirement," Econometrica 58(5): 1151-1180.

World Bank (2012), Life Expectancy at Birth, Total (Years). http://data.worldbank.org/indicator/SP.DYN.LE00.IN. 
Yashiro, N. and T. Oshio (1999). "Social Security and Retirement in Japan." in J. Gruber and D. A. Wise (Eds.) Social Security and Retirement Around the World. Chicago: University of Chicago Press: 239-267.

Zissimopoulos, J., N. Maestas, and L.A. Karoly (2007). "The Effect of Retirement Incentives on Retirement Behavior Evidence from the Self-Employed In the United States and England.” Michigan Retirement Research Center Working Paper 115, Ann Arbor, MI: MRRC. 
Table 1. Dependent Variable Comparisons in the HRS and JSTAR (unweighted)

\begin{tabular}{|c|c|c|c|c|c|c|c|c|c|c|c|c|c|c|}
\hline \multirow[b]{2}{*}{ Variable } & \multicolumn{7}{|c|}{ HRS } & \multicolumn{7}{|c|}{ JSTAR } \\
\hline & mean & std. dev. & edian & $\min$ & $\max$ & nmiss & $N$ & mean & std. dev. & median & $\min$ & $\max$ & nmiss & $N$ \\
\hline Not working & 0.60 & 0.49 & 1 & 0 & 1 & 0 & 9258 & 0.34 & 0.47 & 0 & 0 & 1 & 0 & 2967 \\
\hline Retired & 0.39 & 0.49 & 0 & 0 & 1 & 0 & 9258 & 0.08 & 0.27 & 0 & 0 & 1 & 0 & 2967 \\
\hline Receive SSB & 0.52 & 0.50 & 1 & 0 & 1 & 313 & 8945 & 0.44 & 0.50 & 0 & 0 & 1 & 0 & 2967 \\
\hline Work hours/week & 40.90 & 11.91 & 40 & 0 & 120 & 38 & 3696 & 40.16 & 17.22 & 40 & 0 & 160 & 181 & 1780 \\
\hline Age Expect SSB & 64.80 & 2.37 & 65 & 54 & 70 & 1191 & 2543 & 63.97 & 2.18 & 65 & 60 & 72 & 1046 & 915 \\
\hline
\end{tabular}

Variable Definitions:

Not Working

Retired

Receive SSB

Work hours/week

Age expect SSB

$\begin{array}{cl}\begin{array}{c}\text { Variable } \\ \text { Type }\end{array} & \text { Explanation } \\ 0,1 & =1 \text { if respondent self-reports not working now, } 0 \text { else } \\ 0,1 & =1 \text { if respondent self-reports retired now, } 0 \text { else } \\ 0,1 & =1 \text { if respondent self-reports receiving social security } \\ \text { benefits now, } 0 \text { else }\end{array}$


Table 2. Comparisons of Core Control Variables in the HRS and JSTAR: All Respondents (unweighted)

\begin{tabular}{|c|c|c|c|c|c|c|c|c|c|c|c|c|c|c|}
\hline \multirow[b]{2}{*}{ Variable } & \multicolumn{7}{|c|}{ HRS } & \multicolumn{7}{|c|}{ JSTAR } \\
\hline & mean & std. dev. $n$ & dian & $\min$ & $\max$ & nmiss & $N$ & mean & std. dev. & median & $\min$ & $\max$ & nmiss & $N$ \\
\hline Age & 61.91 & 5.53 & 62 & 50 & 70 & 0 & 9258 & 60.85 & 5.59 & 61 & 50 & 70 & 0 & 2967 \\
\hline Male & 0.40 & 0.49 & 0 & 0 & 1 & 0 & 9258 & 0.51 & 0.50 & 1 & 0 & 1 & 0 & 2967 \\
\hline LT high school & 0.22 & 0.41 & 0 & 0 & 1 & 0 & 9258 & 0.27 & 0.44 & 0 & 0 & 1 & 0 & 2967 \\
\hline High school & 0.48 & 0.50 & 0 & 0 & 1 & 0 & 9258 & 0.49 & 0.50 & 0 & 0 & 1 & 0 & 2967 \\
\hline Some college & 0.19 & 0.39 & 0 & 0 & 1 & 0 & 9258 & 0.22 & 0.42 & 0 & 0 & 1 & 0 & 2967 \\
\hline GT college & 0.10 & 0.30 & 0 & 0 & 1 & 0 & 9258 & 0.01 & 0.10 & 0 & 0 & 1 & 0 & 2967 \\
\hline Married & 0.69 & 0.46 & 1 & 0 & 1 & 0 & 9258 & 0.82 & 0.38 & 1 & 0 & 1 & 1 & 2966 \\
\hline \# living children & 3.16 & 2.06 & 3 & 0 & 18 & 216 & 9042 & 1.95 & 0.88 & 2 & 0 & 3 & 109 & 2858 \\
\hline Children at home & 0.25 & 0.44 & 0 & 0 & 1 & 216 & 9042 & 0.48 & 0.50 & 0 & 0 & 1 & 109 & 2858 \\
\hline Health $<$ average & 0.27 & 0.44 & 0 & 0 & 1 & 5 & 9253 & 0.16 & 0.37 & 0 & 0 & 1 & 11 & 2956 \\
\hline Optim. life exp (75) & 0.41 & 0.49 & 0 & 0 & 1 & 463 & 8795 & 0.66 & 0.48 & 1 & 0 & 1 & 95 & 2872 \\
\hline \# years employed & 33.09 & 13.44 & 36 & 0 & 57 & 0 & 9258 & 30.21 & 13.00 & 34 & 1 & 50 & 228 & 2739 \\
\hline Fin. wealth (US\$) & 100,119 & 463,821 & 5,000 & $-1,450,000$ & $16,820,000$ & 0 & 9258 & 192,890 & $1,208,361$ & 40,950 & $-8,190$ & $24,569,784$ & 1319 & 1648 \\
\hline Fin. wealth $<\$ 0$ & 0.21 & 0.40 & 0 & 0 & 1 & 0 & 9258 & 0.03 & 0.17 & 0 & 0 & 1 & 1319 & 1648 \\
\hline Fin. wealth $\$ 0-\$ 100 \mathrm{k}$ & 0.60 & 0.49 & 1 & 0 & 1 & 0 & 9258 & 0.79 & 0.41 & 1 & 0 & 1 & 1319 & 1648 \\
\hline Fin.wealth $\$ 100-\$ 200 \mathrm{k}$ & 0.07 & 0.25 & 0 & 0 & 1 & 0 & 9258 & 0.11 & 0.32 & 0 & 0 & 1 & 1319 & 1648 \\
\hline Fin. wealth $>=\$ 200 \mathrm{k}$ & 0.13 & 0.33 & 0 & 0 & 1 & 0 & 9258 & 0.07 & 0.25 & 0 & 0 & 1 & 1319 & 1648 \\
\hline
\end{tabular}

$\begin{array}{lcl} & \text { Var. Type } & \text { Explanation } \\ \text { Age (in years) } & \# & \text { Self-reported own age } \\ \text { Male } & 0,1 & =1 \text { if respondent male, } 0 \text { else } \\ \text { LT High School } & \text { reference } & =1 \text { if respondent did not finish high school, } 0 \text { else } \\ \text { High school } & 0,1 & =1 \text { if respondent only finished high school, } 0 \text { else } \\ \text { Some college } & 0,1 & =1 \text { if respondent had some college, } 0 \text { else } \\ \text { GT college } & 0,1 & =1 \text { if respondent had more than college education, } 0 \text { else } \\ \text { Married } & 0,1 & =1 \text { if respondent married or partnered, } 0 \text { else } \\ \text { N living children } & \# & \text { Number of children currently living } \\ \text { Children at home } & 0,1 & =1 \text { if any children living with respondent } \\ \text { Health }<\text { Av } & 0,1 & =1 \text { if self-reported he } \\ \text { Optim. Life Expect (wrt } 75) & 0,1 & =1 \text { if subj. prob. of living to age } 75>\text { country life table } \\ \text { Years employed } & \# & \text { Number of years worked as adult } \\ \text { Financial wealth (US\$) } & \$ & \text { In US 2006 dollars } \\ \text { Fin. wealth }<\$ 0 & \text { reference } & =1 \text { if respondent had wealth }<0,0 \text { else } \\ \text { Fin. wealth } \$ 0-\$ 100 k & 0,1 & =1 \text { if respondent had financial wealth } 0-\$ 100 \mathrm{~K}, 0 \text { else } \\ \text { Fin.wealth } \$ 100-\$ 200 \mathrm{k} & 0,1 & =1 \text { if respondent had financial wealth } \$ 100-\$ 200 \mathrm{~K}, 0 \text { else } \\ \text { Fin. wealth }>=\$ 200 \mathrm{k} & 0,1 & =1 \text { if respondent had financial wealth }>\$ 200 \mathrm{~K}, 0 \text { else }\end{array}$


Table 3. Comparisons of Core Control Variables in the HRS and JSTAR: Workers Only (unweighted)

\begin{tabular}{|c|c|c|c|c|c|c|c|c|c|c|c|c|c|c|}
\hline \multirow[b]{2}{*}{ Variable } & \multicolumn{7}{|c|}{ HRS } & \multicolumn{7}{|c|}{ JSTAR } \\
\hline & mean & std. dev. & median & $\min$ & $\max$ & nmiss & $N$ & mean & std. dev. & median & $\min$ & $\max$ & nmiss & $N$ \\
\hline Age & 59.01 & 4.93 & 58 & 50 & 70 & 0 & 3734 & 59.41 & 5.28 & 59 & 50 & 70 & 0 & 1961 \\
\hline Male & 0.44 & 0.50 & 0 & 0 & 1 & 0 & 3734 & 0.60 & 0.49 & 1 & 0 & 1 & 0 & 1961 \\
\hline LT high school & 0.14 & 0.35 & 0 & 0 & 1 & 0 & 3734 & 0.24 & 0.42 & 0 & 0 & 1 & 0 & 1961 \\
\hline High school & 0.48 & 0.50 & 0 & 0 & 1 & 0 & 3734 & 0.49 & 0.50 & 0 & 0 & 1 & 0 & 1961 \\
\hline Some college & 0.24 & 0.43 & 0 & 0 & 1 & 0 & 3734 & 0.26 & 0.44 & 0 & 0 & 1 & 0 & 1961 \\
\hline GT college & 0.13 & 0.33 & 0 & 0 & 1 & 0 & 3734 & 0.01 & 0.12 & 0 & 0 & 1 & 0 & 1961 \\
\hline Married & 0.71 & 0.45 & 1 & 0 & 1 & 0 & 3734 & 0.83 & 0.37 & 1 & 0 & 1 & 0 & 1961 \\
\hline \# living children & 2.98 & 1.97 & 3 & 0 & 16 & 81 & 3653 & 1.97 & 0.87 & 2 & 0 & 3 & 73 & 1888 \\
\hline Children at home & 0.33 & 0.47 & 0 & 0 & 1 & 81 & 3653 & 0.53 & 0.50 & 1 & 0 & 1 & 73 & 1888 \\
\hline Health $<$ average & 0.16 & 0.37 & 0 & 0 & 1 & 1 & 3733 & 0.11 & 0.31 & 0 & 0 & 1 & 6 & 1955 \\
\hline Optim. life exp (75) & 0.42 & 0.49 & 0 & 0 & 1 & 140 & 3594 & 0.66 & 0.47 & 1 & 0 & 1 & 55 & 1906 \\
\hline \# years employed & 36.40 & 9.86 & 38 & 0 & 57 & 0 & 3734 & 31.97 & 11.68 & 35 & 1 & 50 & 104 & 1857 \\
\hline Fin. wealth (US\$) & 78,153 & 349,605 & 5,000 & $-1,200,000$ & $10,221,000$ & 0 & 3734 & 196,836 & $1,301,851$ & 40,950 & $-8,190$ & $24,569,784$ & 858 & 1103 \\
\hline Fin. wealth $<\$ 0$ & 0.24 & 0.43 & 0 & 0 & 1 & 0 & 3734 & 0.03 & 0.18 & 0 & 0 & 1 & 858 & 1103 \\
\hline Fin. wealth $\$ 0-\$ 100 \mathrm{k}$ & 0.58 & 0.49 & 1 & 0 & 1 & 0 & 3734 & 0.80 & 0.40 & 1 & 0 & 1 & 858 & 1103 \\
\hline Fin.wealth $\$ 100-\$ 200 \mathrm{k}$ & 0.07 & 0.25 & 0 & 0 & 1 & 0 & 3734 & 0.10 & 0.31 & 0 & 0 & 1 & 858 & 1103 \\
\hline Fin. wealth $>=\$ 200 \mathrm{k}$ & 0.11 & 0.31 & 0 & 0 & 1 & 0 & 3734 & 0.07 & 0.25 & 0 & 0 & 1 & 858 & 1103 \\
\hline
\end{tabular}

Variable Definitions: See Table 2 
Table 4. Determinants of Probability of Not Working (Logit model) : All Respondents

\begin{tabular}{|c|c|c|c|c|c|}
\hline HRS variable & Estimate & Marginal & *JSTAR & \multicolumn{2}{|c|}{ Estimate Marginal } \\
\hline Age & 0.25 & $6.22 * * *$ & J*Age & -0.06 & $-1.47 * * *$ \\
\hline Male & 0.15 & $3.65 * *$ & $\mathrm{~J} *$ Male & -0.93 & $-22.61 * * *$ \\
\hline High School & -0.10 & -2.50 & J*High School & 0.23 & $5.80 *$ \\
\hline Some college & -0.37 & $-9.33 * * *$ & $\mathrm{~J} *$ Some college & 0.32 & $7.79 *$ \\
\hline GT college & -0.58 & $-14.27 * * *$ & $\mathrm{~J}^{*} \mathrm{GT}$ college & -0.37 & -9.21 \\
\hline Married & 0.08 & 1.97 & $\mathrm{~J} *$ Married & 0.12 & 3.07 \\
\hline \# living children & -0.04 & $-1.01 * *$ & $\mathrm{~J} * \mathrm{~N}$ living children & -0.12 & $-2.92 * *$ \\
\hline Children at home & -0.35 & $-8.79 * * *$ & $\mathrm{~J} *$ Children at home & 0.03 & 0.80 \\
\hline Health $<$ average & 1.00 & $23.69 * * *$ & $\mathrm{~J}^{*}$ Health $<$ average & 0.01 & 0.20 \\
\hline Optim. Life exp. & -0.17 & $-4.14 * * *$ & J*Optim. Life exp. & -0.03 & -0.65 \\
\hline \# years employed & -0.09 & $-2.21 * * *$ & $\mathrm{~J}^{* \#}$ years employed & 0.04 & $1.12 * * *$ \\
\hline Fin. wealth $\$ 0-\$ 100 \mathrm{k}$ & 0.25 & $6.13 * * *$ & J*Fin. wealth $\$ 0-\$ 100 \mathrm{k}$ & -0.23 & -5.63 \\
\hline Fin.wealth $\$ 100-\$ 200 \mathrm{k}$ & 0.30 & $7.49 * *$ & $\mathrm{~J} *$ Fin.wealth $\$ 100-\$ 200 \mathrm{k}$ & 0.20 & 5.04 \\
\hline \multirow[t]{2}{*}{ Fin. wealth $>=\$ 200 \mathrm{k}$} & 0.61 & $14.82 * * *$ & $\mathrm{~J} *$ Fin. wealth $>=\$ 200 \mathrm{k}$ & -0.31 & -7.73 \\
\hline & & & $\mathrm{J} *$ intercept & 1.50 & $34.11 *$ \\
\hline $\mathrm{N}$ & 11,319 & & & & \\
\hline R-squared & 0.35 & & & & \\
\hline Mean dep var & 0.60 & & & 0.34 & \\
\hline
\end{tabular}

Variable definitions: See Tables 1 and 2

Note: Controls for missing control variables also included. 
Table 5. Determinants of Being Retired now (Logit model): All Respondents (unweighted)

\begin{tabular}{|c|c|c|c|c|c|}
\hline HRS Variable & Estimate & Marginal & *JSTAR & Estimate & Marginal \\
\hline Age & 0.22 & $4.30 * * *$ & $\mathrm{~J}^{*}$ Age & 0.03 & $0.63 *$ \\
\hline Male & 0.27 & $5.09 * * *$ & $\mathrm{~J}^{*}$ Male & 1.60 & $35.74 * * *$ \\
\hline High School & 0.10 & 1.90 & J*High School & 0.20 & 3.81 \\
\hline Some college & -0.06 & -1.06 & $\mathrm{~J}^{*}$ Some college & 0.46 & $9.28 *$ \\
\hline GT college & -0.17 & -3.01 & $\mathrm{~J} * \mathrm{GT}$ college & -0.18 & -3.12 \\
\hline Married & -0.14 & $-2.68 * *$ & $\mathrm{~J} *$ Married & -0.16 & -2.81 \\
\hline \# living children & -0.02 & -0.34 & $\mathrm{~J}^{*} \mathrm{~N}$ living children & -0.09 & -1.65 \\
\hline Children at home & -0.42 & $-7.35 * * *$ & $\mathrm{~J} *$ Children at home & 0.21 & 4.03 \\
\hline Health $<$ average & 0.70 & $14.08 * * *$ & $\mathrm{~J}^{*}$ Health $<$ average & -0.46 & $-7.57 * *$ \\
\hline Optim. Life exp. & -0.21 & $-3.85 * * *$ & $\mathrm{~J}^{*}$ Optim. Life exp. & 0.35 & $6.80 *$ \\
\hline \# years employed & -0.02 & $-0.37 * * *$ & $\mathrm{~J}^{* \#}$ years employed & 0.03 & $0.54 * * *$ \\
\hline Fin. wealth $\$ 0-\$ 100 \mathrm{k}$ & 0.19 & $3.45 * * *$ & $\mathrm{~J} *$ Fin. wealth $\$ 0-\$ 100 \mathrm{k}$ & -0.41 & -6.93 \\
\hline Fin.wealth $\$ 100-\$ 200 \mathrm{k}$ & 0.36 & $7.05 * * *$ & $\mathrm{~J} *$ Fin.wealth $\$ 100-\$ 200 \mathrm{k}$ & -0.15 & -2.65 \\
\hline \multirow[t]{2}{*}{ Fin. wealth $>=\$ 200 \mathrm{k}$} & 0.61 & $12.51 * * *$ & $\mathrm{~J} *$ Fin. wealth $>=\$ 200 \mathrm{k}$ & -0.74 & -11.11 \\
\hline & & & $\mathrm{J}^{*}$ intercept & -6.30 & $-59.43 * * *$ \\
\hline $\mathrm{N}$ & 11,319 & & & & \\
\hline R-squared & 0.33 & & & & \\
\hline Mean dep var & 0.39 & & & 0.08 & \\
\hline
\end{tabular}


Table 6. Determinants of Probability of Receiving Social Security Benefits (Logit model): All Respondents (unweighted)

\begin{tabular}{|c|c|c|c|c|c|}
\hline HRS variable & Estimate & Targinal & *JSTAR & Estimate & Marginal \\
\hline Age & 0.52 & $12.85 * * *$ & $\mathrm{~J}^{*}$ Age & -0.01 & -0.31 \\
\hline Male & 0.39 & $9.67 * * *$ & $\mathrm{~J}^{*}$ Male & -0.62 & $-15.26 * * *$ \\
\hline High School & -0.28 & $-7.03 * * *$ & J*High School & 0.27 & 6.84 \\
\hline Some college & -0.75 & $-18.37 * * *$ & $\mathrm{~J} *$ Some college & 0.69 & $16.67 * * *$ \\
\hline GT college & -1.17 & $-26.74 * * *$ & $\mathrm{~J} * \mathrm{GT}$ college & 0.14 & 3.45 \\
\hline Married & -0.44 & $-10.97 * * *$ & $\mathrm{~J} *$ Married & -0.63 & $-15.43 * * *$ \\
\hline \# living children & -0.01 & -0.29 & $\mathrm{~J} * \mathrm{~N}$ living children & 0.11 & 2.72 \\
\hline Children at home & -0.34 & $-8.40 * * *$ & $\mathrm{~J}^{*}$ Children at home & 0.37 & $9.07 * *$ \\
\hline Health $<$ average & 1.14 & $27.23 * * *$ & $\mathrm{~J}^{*}$ Health $<$ average & -0.90 & $-21.12 * * *$ \\
\hline Optim. Life exp. & -0.03 & -0.65 & J*Optim. Life exp. & 0.10 & 2.41 \\
\hline \# years employed & -0.05 & $-1.13 * * *$ & $\mathrm{~J}^{*} \#$ years employed & 0.05 & $1.31 * * *$ \\
\hline Fin. wealth $\$ 0-\$ 100 \mathrm{k}$ & -0.01 & -0.16 & $\mathrm{~J}^{*}$ Fin. wealth $\$ 0-\$ 100 \mathrm{k}$ & 0.47 & 11.59 \\
\hline Fin.wealth $\$ 100-\$ 200 \mathrm{k}$ & -0.29 & $-7.20 * *$ & J*Fin.wealth $\$ 100-\$ 200 \mathrm{k}$ & 0.91 & 21.40 \\
\hline \multirow[t]{2}{*}{ Fin. wealth $>=\$ 200 \mathrm{k}$} & -0.12 & -2.96 & $\mathrm{~J} *$ Fin. wealth $>=\$ 200 \mathrm{k}$ & 0.84 & 19.84 \\
\hline & & & $\mathrm{J} *$ intercept & -1.21 & -28.65 \\
\hline $\mathrm{N}$ & 11,912 & & & & \\
\hline R-squared & 0.53 & & & & \\
\hline Mean of dep var & 0.52 & & & 0.44 & \\
\hline
\end{tabular}

Variable definitions: See Table 1 and 2.

Note: Controls for missing control variables also included. 
Table 7. Determinants of Work Hours (OLS): Workers Only (unweighted)

\begin{tabular}{lclc} 
HRS variable & Estimate & *JSTAR & Estimate \\
\hline Age & $-0.29 * * *$ & $\mathrm{~J} *$ Age & $-0.57 * * *$ \\
Male & $6.14 * * *$ & $\mathrm{~J} *$ Male & $3.81 * * *$ \\
High School & -0.56 & $\mathrm{~J} *$ High School & $-2.39 * *$ \\
Some college & 0.06 & $\mathrm{~J}$ *Some college & -2.14 \\
GT college & $2.31 * * *$ & $\mathrm{~J} *$ GT college & 3.68 \\
Married & -0.66 & $\mathrm{~J} *$ Married & $-2.18 *$ \\
\# living children & -0.09 & $\mathrm{~J} *$ N living children & 0.12 \\
Children at home & -0.61 & $\mathrm{~J}$ Children at home & 0.39 \\
Health $<$ average & 0.05 & $\mathrm{~J} *$ Health $<$ average & -2.07 \\
Optim. Life exp. & 0.16 & $\mathrm{~J} *$ Optim. Life exp. & 0.88 \\
\# years employed & $0.16 * * *$ & $\mathrm{~J} * \#$ years employed & $0.13 * *$ \\
Fin. wealth $\$ 0-\$ 100 \mathrm{k}$ & -0.44 & $\mathrm{~J} *$ Fin. wealth $\$ 0-\$ 100 \mathrm{k}$ & -3.50 \\
Fin.wealth $\$ 100-\$ 200 \mathrm{k}$ & -0.06 & $\mathrm{~J} *$ Fin.wealth $\$ 100-\$ 200 \mathrm{k}$ & $-6.25 * *$ \\
Fin. wealth $>=\$ 200 \mathrm{k}$ & 0.18 & $\mathrm{~J} *$ Fin. wealth $>=\$ 200 \mathrm{k}$ & $-5.63 *$ \\
& & $\mathrm{~J} *$ intercept & $33.38 * * *$ \\
\hline N & 5,476 & & \\
R-squared & 0.16 & & \\
Mean dep var & 40.9 & & 40.2
\end{tabular}

Variable definitions: See Tables 1 and 2

Note: Controls for missing control variables also included. 
Table 8: Comparisons of Additional Control Variables in the HRS and JSTAR: All Respondents (unweighted)

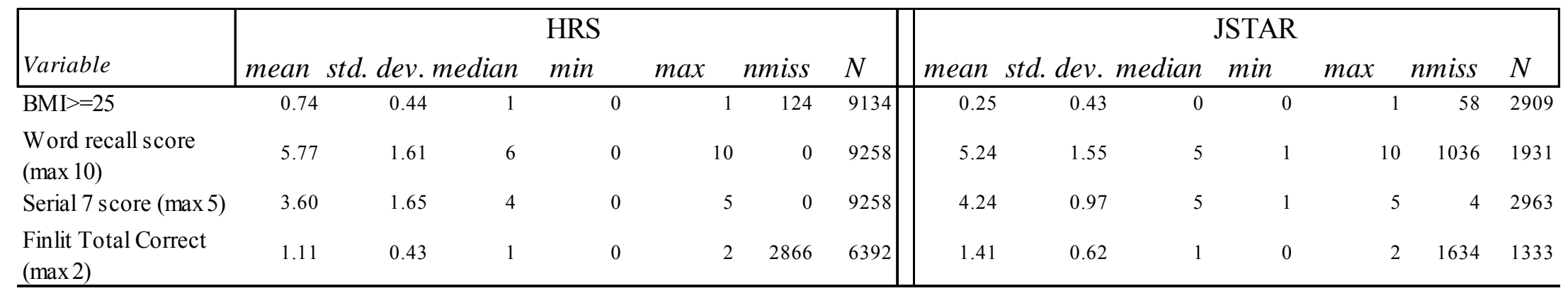

Variable definitions: See Tables 1 and 2

Note: Controls for missing control variables also included.

Table 9: Comparisons of Additional Variables in the HRS and JSTAR: Workers Only (unweighted)

\begin{tabular}{|c|c|c|c|c|c|c|c|c|c|c|c|c|c|c|}
\hline \multirow[b]{2}{*}{ Variable } & \multicolumn{7}{|c|}{ HRS } & \multicolumn{7}{|c|}{ JSTAR } \\
\hline & mean & std. dev & median & $\min$ & $\max$ & nmiss & $N$ & mean & std. dev. & median & $\min$ & $\max$ & nmiss & $N$ \\
\hline $\mathrm{BMI}>=25$ & 0.74 & 0.44 & 1 & 0 & 1 & 46 & 3688 & 0.25 & 0.43 & 0 & 0 & 1 & 31 & 1930 \\
\hline $\begin{array}{l}\text { Word recall score } \\
(\max 10)\end{array}$ & 6.07 & 1.53 & 6 & 0 & 10 & 0 & 3734 & 5.30 & 1.54 & 5 & 1 & 10 & 662 & 1299 \\
\hline Serial 7 score $(\max 5)$ & 3.89 & 1.47 & 5 & 0 & 5 & 0 & 3734 & 4.30 & 0.93 & 5 & 1 & 5 & 2 & 1959 \\
\hline $\begin{array}{l}\text { Finlit Total Correct } \\
(\max 2)\end{array}$ & 1.14 & 0.45 & 1 & 0 & 2 & 911 & 2823 & 1.43 & 0.60 & 1 & 0 & 2 & 1009 & 952 \\
\hline
\end{tabular}

Variable definitions: See Tables 1 and 2

Note: Controls for missing control variables also included. 
Table 10: Additional Determinants of Not Working (Logit model): All Respondents (unweighted)

\begin{tabular}{|c|c|c|c|c|c|c|}
\hline HRS variable & Estimate & Marginal & *JSTAR & Estimate & Marginal & \\
\hline Age & 0.25 & $6.16 * * *$ & $\mathrm{~J} *$ Age & -0.05 & -1.34 & $* * *$ \\
\hline Male & 0.12 & $2.94 *$ & $\mathrm{~J}^{*}$ Male & -0.95 & -23.06 & $* * *$ \\
\hline High School & -0.01 & -0.22 & J*High School & 0.13 & 3.27 & \\
\hline Some college & -0.22 & $-5.57 * *$ & $\mathrm{~J}^{*}$ Some college & 0.13 & 3.27 & \\
\hline GT college & -0.39 & $-9.59 * * *$ & $\mathrm{~J} * \mathrm{GT}$ college & -0.68 & -16.53 & \\
\hline Married & 0.09 & 2.36 & $\mathrm{~J} *$ Married & 0.11 & 2.74 & \\
\hline \# living children & -0.04 & $-1.10 * * *$ & $\mathrm{~J} * \mathrm{~N}$ living children & -0.11 & -2.80 & $* *$ \\
\hline Children at home & -0.36 & $-9.01 * * *$ & $\mathrm{~J}^{*}$ Children at home & 0.03 & 0.82 & \\
\hline Health $<$ average & 0.96 & $22.82 * * *$ & $\mathrm{~J}^{*}$ Health $<$ average & 0.04 & 1.02 & \\
\hline Optim. Life exp. & -0.16 & $-4.02 * * *$ & J*Optim. Life exp. & -0.02 & -0.58 & \\
\hline \# years employed & -0.09 & $-2.17 * * *$ & $\mathrm{~J}^{* \#}$ years employed & 0.04 & 1.09 & $* * *$ \\
\hline Fin. wealth $\$ 0-\$ 100 \mathrm{k}(\%)$ & 0.25 & $6.24 * * *$ & $\mathrm{~J}^{*}$ Fin. wealth $\$ 0-\$ 100 \mathrm{k}(\%)$ & -0.21 & -5.32 & \\
\hline Fin.wealth \$100-\$200k (\%) & 0.34 & $8.42 * * *$ & $\mathrm{~J} *$ Fin.wealth $\$ 100-\$ 200 \mathrm{k}(\%)$ & 0.16 & 4.07 & \\
\hline Fin. wealth $>=\$ 200 \mathrm{k}(\%)$ & 0.66 & $15.83 * * *$ & $\mathrm{~J}^{*}$ Fin. wealth $>=\$ 200 \mathrm{k}(\%)$ & -0.34 & -8.48 & \\
\hline $\mathrm{BMI}>=25$ & 0.10 & 2.57 & $\mathrm{~J} * \mathrm{BMI}>=25$ & -0.01 & -0.28 & \\
\hline Word recall score $(\max 10)$ & -0.06 & $-1.44 * * *$ & $\mathrm{~J} *$ Word recall score $(\max 10)$ & 0.01 & 0.19 & \\
\hline Serial 7 score $(\max 5)$ & -0.05 & $-1.21 * *$ & $\mathrm{~J}^{*}$ Serial 7 score $(\max 5)$ & 0.04 & 1.05 & \\
\hline \multirow[t]{2}{*}{ Finlit Total Correct $(\max 2)$} & -0.09 & -2.24 & $\mathrm{~J}^{*}$ Finlit Total Correct $(\max 2)$ & 0.19 & 4.61 & $* *$ \\
\hline & & & $\mathrm{J} *$ intercept & 0.96 & 22.80 & \\
\hline $\mathrm{N}$ & 11,319 & & & & & \\
\hline R-squared & 0.35 & & & & & \\
\hline Mean dep var & 0.60 & & & 0.34 & & \\
\hline
\end{tabular}

Variable definitions: See Tables 1 and 2

Note: Controls for missing control variables also included. 
Table 11: Additional Determinants of Being Retired now (Logit model): All Respondents (unweighted)

\begin{tabular}{|c|c|c|c|c|c|c|}
\hline HRS Variable & Estimate & Marginal & *JSTAR & Estimate & Marginal & \\
\hline Age & 0.22 & $4.25 * * *$ & $\mathrm{~J} *$ Age & 0.04 & $0.75 *$ & \\
\hline Male & 0.25 & $4.68 * * *$ & $\mathrm{~J} *$ Male & 1.58 & $35.28 *$ & $* * *$ \\
\hline High School & 0.14 & $2.56 *$ & J*High School & 0.20 & 3.71 & \\
\hline Some college & 0.02 & 0.38 & $\mathrm{~J} *$ Some college & 0.40 & 8.03 & \\
\hline GT college & -0.06 & -1.07 & $\mathrm{~J} *$ GT college & -0.26 & -4.38 & \\
\hline Married & -0.15 & $-2.73 * *$ & $\mathrm{~J} *$ Married & -0.21 & -3.67 & \\
\hline \# living children & -0.02 & -0.35 & $\mathrm{~J} * \mathrm{~N}$ living children & -0.06 & -1.16 & \\
\hline Children at home & -0.42 & $-7.29 * * *$ & $\mathrm{~J} *$ Children at home & 0.19 & 3.68 & \\
\hline Health $<$ average & 0.68 & $13.52 * * *$ & $\mathrm{~J} *$ Health $<$ average & -0.50 & -7.97 & $* *$ \\
\hline Optim. Life exp. & -0.20 & $-3.66 * * *$ & $\mathrm{~J} *$ Optim. Life exp. & 0.34 & $6.67 *$ & $*$ \\
\hline \# years employed & -0.02 & $-0.36 * * *$ & $\mathrm{~J}^{*} \#$ years employed & 0.03 & $0.55 *$ & $* * *$ \\
\hline Fin. wealth $\$ 0-\$ 100 \mathrm{k}$ & 0.20 & $3.61 * * *$ & $\mathrm{~J}^{*}$ Fin. wealth $\$ 0-\$ 100 \mathrm{k}$ & -0.47 & -7.75 & \\
\hline Fin.wealth $\$ 100-\$ 200 \mathrm{k}$ & 0.39 & $7.66 * * *$ & J*Fin.wealth $\$ 100-\$ 200 \mathrm{k}$ & -0.24 & -4.13 & \\
\hline Fin. wealth $>=\$ 200 \mathrm{k}$ & 0.65 & $13.44 * * *$ & $\mathrm{~J} *$ Fin. wealth $>=\$ 200 \mathrm{k}$ & -0.84 & -12.03 & \\
\hline $\mathrm{BMI}>=25$ & 0.13 & $2.35 * *$ & $\mathrm{~J} * \mathrm{BMI}>=25$ & -0.22 & -3.83 & \\
\hline Word recall score $(\max 10)$ & -0.04 & $-0.68 *$ & $\mathrm{~J} * \mathrm{~W}$ ord recall score $(\max 10)$ & -0.09 & -1.53 & \\
\hline Serial 7 score $(\max 5)$ & -0.03 & -0.50 & $\mathrm{~J} *$ Serial 7 score $(\max 5)$ & -0.10 & -1.85 & \\
\hline \multirow[t]{2}{*}{ Finlit Total Correct $(\max 2)$} & -0.21 & $-3.70 * * *$ & $\mathrm{~J} *$ Finlit Total Correct $(\max 2)$ & 0.20 & 3.84 & $*$ \\
\hline & & & $\mathrm{J} *$ intercept & -5.91 & -56.70 & $* * *$ \\
\hline $\mathrm{N}$ & 11,319 & & & & & \\
\hline R-squared & 0.33 & & & & & \\
\hline Mean dep var & 0.39 & & & 0.08 & & \\
\hline
\end{tabular}

Variable definitions: See Tables 1 and 2

Note: Controls for missing control variables also included. 
Table 12: Additional Determinants of Probability of Currently Receiving Social Security Benefits (Logit model): All Respondents (unweighted)

\begin{tabular}{|c|c|c|c|c|c|c|}
\hline HRS Variable & Estimate & Marginal & *JSTAR & Estimate & Marginal & \\
\hline Age & 0.52 & $12.80 * * *$ & J*Age & -0.01 & -0.29 & \\
\hline Male & 0.31 & $7.78 * * *$ & $\mathrm{~J} *$ Male & -0.55 & $-13.48 *$ & $* * *$ \\
\hline High School & -0.15 & -3.70 & J*High School & 0.14 & 3.54 & \\
\hline Some college & -0.55 & $-13.51 * * *$ & $\mathrm{~J} *$ Some college & 0.48 & $11.86 *$ & $* *$ \\
\hline GT college & -0.92 & $-21.74 * * *$ & $\mathrm{~J} * \mathrm{GT}$ college & -0.09 & -2.29 & \\
\hline Married & -0.42 & $-10.46 * * *$ & $\mathrm{~J} *$ Married & -0.65 & $-16.05 *$ & $* * *$ \\
\hline \# living children & -0.02 & -0.40 & $\mathrm{~J} * \mathrm{~N}$ living children & 0.11 & 2.76 & \\
\hline Children at home & -0.35 & $-8.75 * * *$ & $\mathrm{~J}^{*}$ Children at home & 0.37 & 9.21 & $* *$ \\
\hline Health $<$ average & 1.08 & $25.99 * * *$ & $\mathrm{~J}^{*}$ Health $<$ average & -0.84 & $-19.84 *$ & $* * *$ \\
\hline Optim. Life exp. & -0.02 & -0.39 & J*Optim. Life exp. & 0.07 & 1.74 & \\
\hline \# years employed & -0.04 & $-1.08 * * *$ & $\mathrm{~J}^{* \#}$ years employed & 0.05 & $1.26 *$ & $* * *$ \\
\hline Fin. wealth $\$ 0-\$ 100 \mathrm{k}$ & -0.01 & -0.19 & $\mathrm{~J}^{*}$ Fin. wealth $\$ 0-\$ 100 \mathrm{k}$ & 0.44 & 10.91 & \\
\hline Fin.wealth $\$ 100-\$ 200 \mathrm{k}$ & -0.24 & $-6.02 *$ & J*Fin.wealth $\$ 100-\$ 200 \mathrm{k}$ & 0.83 & 19.67 & \\
\hline Fin. wealth $>=\$ 200 \mathrm{k}$ & -0.07 & -1.65 & $\mathrm{~J}^{*}$ Fin. wealth $>=\$ 200 \mathrm{k}$ & 0.76 & 18.19 & \\
\hline $\mathrm{BMI}>=25$ & 0.10 & 2.45 & $\mathrm{~J} * \mathrm{BMI}>=25$ & -0.18 & -4.37 & \\
\hline Word recall score $(\max 10)$ & -0.10 & $-2.61 * * *$ & $\mathrm{~J} *$ Word recall score $(\max 10)$ & 0.09 & 2.33 & $*$ \\
\hline Serial 7 score $(\max 5)$ & -0.06 & $-1.38 * *$ & $\mathrm{~J} *$ Serial 7 score $(\max 5)$ & 0.09 & 2.13 & \\
\hline \multirow[t]{2}{*}{ Finlit Total Correct $(\max 2)$} & -0.01 & -0.37 & $\mathrm{~J} *$ Finlit Total Correct $(\max 2)$ & 0.01 & 0.30 & \\
\hline & & & $\mathrm{J} *$ intercept & -1.85 & -41.13 & \\
\hline $\mathrm{N}$ & 11,912 & & & & & \\
\hline R-squared & 0.54 & & & & & \\
\hline Mean dep var & 0.52 & & & 0.44 & & \\
\hline
\end{tabular}

Variable definitions: See Tables 1 and 2

Note: Controls for missing control variables also included. 
Table 13: Additional Determinants of Work Hours (OLS): Workers Only (unweighted)

\begin{tabular}{|c|c|c|c|}
\hline HRS variable & Estimate & *JSTAR & Estimate \\
\hline Age & $-0.28 * * *$ & $\mathrm{~J} *$ Age & $-0.59 * * *$ \\
\hline Male & $6.10 * * *$ & $\mathrm{~J} *$ Male & $4.05 * * *$ \\
\hline High School & -0.70 & J*High School & $-2.02 *$ \\
\hline Some college & -0.19 & $\mathrm{~J} *$ Some college & -1.56 \\
\hline GT college & $2.10 * *$ & $\mathrm{~J} * \mathrm{GT}$ college & 4.33 \\
\hline Married & $-0.71 *$ & $\mathrm{~J} *$ Married & $-2.19 *$ \\
\hline \# living children & -0.10 & $\mathrm{~J}^{*} \mathrm{~N}$ living children & 0.15 \\
\hline Children at home & -0.61 & $\mathrm{~J}^{*}$ Children at home & 0.44 \\
\hline Health $<$ average & 0.07 & $\mathrm{~J}^{*}$ Health $<$ average & -2.10 \\
\hline Optim. Life exp. & 0.15 & J*Optim. Life exp. & 0.94 \\
\hline \# years employed & $0.16 * * *$ & $\mathrm{~J}^{*} \#$ years employed & $0.14 * * *$ \\
\hline Fin. wealth $\$ 0-\$ 100 \mathrm{k}$ & -0.37 & $\mathrm{~J}^{*}$ Fin. wealth $\$ 0-\$ 100 \mathrm{k}$ & -3.49 \\
\hline Fin.wealth $\$ 100-\$ 200 \mathrm{k}$ & 0.03 & J*Fin.wealth $\$ 100-\$ 200 \mathrm{k}$ & $-6.13 * *$ \\
\hline Fin. wealth $>=\$ 200 \mathrm{k}$ & 0.32 & $\mathrm{~J} *$ Fin. wealth $>=\$ 200 \mathrm{k}$ & $-5.56 *$ \\
\hline $\mathrm{BMI}>=25$ & $1.28 * * *$ & $\mathrm{~J} * \mathrm{BMI}>=25$ & -1.04 \\
\hline Word recall score $(\max 10)$ & 0.18 & $\mathrm{~J} *$ Word recall score $(\max 10)$ & 0.04 \\
\hline Serial 7 score $(\max 5)$ & 0.13 & $\mathrm{~J} *$ Serial 7 score $(\max 5)$ & -0.40 \\
\hline \multirow[t]{2}{*}{ Finlit Total Correct $(\max 2)$} & 0.21 & $\mathrm{~J} *$ Finlit Total Correct $(\max 2)$ & -0.54 \\
\hline & & $\mathrm{J} *$ intercept & $36.77 * * *$ \\
\hline $\mathrm{N}$ & 5,476 & & \\
\hline R-squared & 0.16 & & \\
\hline Mean dep var & 40.9 & & 40.2 \\
\hline
\end{tabular}

Variable definitions: See Tables 1 and 2

Note: Controls for missing control variables also included. 
Table 14. Determinants of Age Expect to Receive SSB (OLS): Workers Only (unweighted)

\begin{tabular}{lclc} 
HRS variable & Estimate & *JSTAR & Estimate \\
\hline Age & $0.11 * * *$ & $\mathrm{~J} *$ Age & $-0.10 * * *$ \\
Male & 0.09 & $\mathrm{~J} *$ Male & 0.18 \\
High School & $0.47 * * *$ & $\mathrm{~J} *$ High School & $-0.91 * * *$ \\
Some college & $0.75 * * *$ & $\mathrm{~J} *$ Some college & $-0.74 * * *$ \\
GT college & $1.35 * * *$ & $\mathrm{~J} *$ GT college & 0.14 \\
Married & 0.03 & $\mathrm{~J} *$ Married & -0.34 \\
\# living children & -0.04 & $\mathrm{~J} *$ N living children & -0.01 \\
Children at home & 0.08 & $\mathrm{~J} *$ Children at home & 0.09 \\
Health $<$ average & -0.03 & $\mathrm{~J} *$ Health $<$ average & 0.01 \\
Optim. Life exp. & $0.36 * * *$ & $\mathrm{~J} *$ Optim. Life exp. & -0.21 \\
\# years employed & 0.01 & $\mathrm{~J} * \#$ years employed & -0.01 \\
Fin. wealth $\$ 0-\$ 100 \mathrm{k}$ & $-0.36 * * *$ & $\mathrm{~J} *$ Fin. wealth $\$ 0-\$ 100 \mathrm{k}$ & 0.55 \\
Fin.wealth $\$ 100-\$ 200 \mathrm{k}$ & $-0.42 * *$ & $\mathrm{~J} *$ Fin.wealth $\$ 100-\$ 200 \mathrm{k}$ & 0.34 \\
Fin. wealth $>=\$ 200 \mathrm{k}$ & $-0.44 * *$ & $\mathrm{~J} *$ Fin. wealth $>=\$ 200 \mathrm{k}$ & 0.57 \\
& & $\mathrm{~J} *$ intercept & $5.68 * * *$ \\
\hline N & & \\
R-squared & & \\
Mean dep var & 64.458 & \\
Variable definitions: See Tables 1 and 2 \\
Note: Controls for missing control variables also included.
\end{tabular}


Table 15. Additional Determinants of Age Expect to Receive SSB (OLS): Workers Only (unweighted)

\begin{tabular}{lclc} 
HRS variable & Estimate & $*$ JSTAR & Estimate \\
\hline Age & $0.11 * * *$ & $\mathrm{~J} *$ Age & $-0.10 * * *$ \\
Male & 0.11 & $\mathrm{~J} *$ Male & 0.13 \\
High School & $0.27 *$ & $\mathrm{~J} *$ High School & $-0.74 * * *$ \\
Some college & $0.42 * *$ & $\mathrm{~J} *$ Some college & -0.46 \\
GT college & $0.95 * * *$ & $\mathrm{~J} *$ GT college & 0.48 \\
Married & 0.01 & $\mathrm{~J} *$ Married & -0.29 \\
\# living children & -0.03 & $\mathrm{~J} *$ N living children & -0.02 \\
Children at home & 0.08 & $\mathrm{~J} *$ Children at home & 0.09 \\
Health $<$ average & 0.04 & $\mathrm{~J} *$ Health $<$ average & -0.04 \\
Optim. Life exp. & $0.35 * * *$ & $\mathrm{~J} *$ Optim. Life exp. & -0.19 \\
\# years employed & 0.00 & $\mathrm{~J} * \#$ years employed & -0.01 \\
Fin. wealth $\$ 0-\$ 100 \mathrm{k}$ & $-0.37 * * *$ & $\mathrm{~J} *$ Fin. wealth $\$ 0-\$ 100 \mathrm{k}$ & 0.51 \\
Fin.wealth $\$ 100-\$ 200 \mathrm{k}$ & $-0.49 * *$ & $\mathrm{~J} *$ Fin.wealth $\$ 100-\$ 200 \mathrm{k}$ & 0.34 \\
Fin. wealth $>=\$ 200 \mathrm{k}$ & $-0.52 * * *$ & $\mathrm{~J} *$ Fin. wealth $>=\$ 200 \mathrm{k}$ & 0.57 \\
BMI>=25 & $-0.20 *$ & $\mathrm{~J} *$ BMI $>25$ & 0.17 \\
Word recall score $(\max 10)$ & $0.08 * *$ & $\mathrm{~J} *$ Word recall score $(\max 10)$ & $-0.13 *$ \\
Serial 7 score $(\max 5)$ & $0.11 * * *$ & $\mathrm{~J} *$ Serial 7 score $(\max 5)$ & -0.06 \\
Finlit Total Correct $(\max 2)$ & $0.19 *$ & $\mathrm{~J} *$ Finlit Total Correct $(\max 2)$ & -0.15 \\
& & $\mathrm{~J} *$ intercept & $6.38 * * *$ \\
\hline N & 3,458 & & 63.97 \\
R-squared & 0.09 & & \\
Mean dep var & 64.80 & & \\
& & &
\end{tabular}

Variable definitions: See Tables 1 and 2

Note: Controls for missing control variables also included. 
Appendix Table 1. Work at Older ages in Japan and the US: Self-reported Retirement by Sex (unweighted)

\begin{tabular}{|c|c|c|c|c|c|c|c|c|c|}
\hline \multirow{2}{*}{$\begin{array}{l}\text { Men } \\
\text { Variable }\end{array}$} & \multirow[b]{2}{*}{ Sample } & \multicolumn{3}{|c|}{ HRS } & \multicolumn{5}{|c|}{ JST AR } \\
\hline & & $50-55$ & $56-60$ & $61-65$ & $66-70$ & $50-55$ & $56-60$ & $61-65$ & $66-70$ \\
\hline Work hours & Total & 45.82 & 44.25 & 45.50 & 43.72 & 49.08 & 46.53 & 43.11 & 38.21 \\
\hline $\begin{array}{l}\text { \% Reporting work } \\
\text { hours }\end{array}$ & Total & 0.73 & 0.66 & 0.38 & 0.20 & 0.93 & 0.88 & 0.63 & 0.45 \\
\hline $\begin{array}{l}\text { Self-rep. health }<\text { av. } \\
(\%)\end{array}$ & Workers & 0.14 & 0.18 & 0.15 & 0.18 & 0.08 & 0.11 & 0.10 & 0.13 \\
\hline $\mathrm{BMI}>=25$ & Workers & 0.80 & 0.82 & 0.82 & 0.74 & 0.29 & 0.26 & 0.30 & 0.26 \\
\hline $\mathrm{BMI}>=30$ & Workers & 0.34 & 0.34 & 0.34 & 0.33 & 0.03 & 0.04 & 0.02 & 0.02 \\
\hline Low education & Workers & 0.34 & 0.33 & 0.45 & 0.46 & 0.51 & 0.67 & 0.73 & 0.87 \\
\hline High education & Workers & 0.66 & 0.67 & 0.55 & 0.54 & 0.49 & 0.33 & 0.27 & 0.13 \\
\hline $\begin{array}{l}\text { Word recall score } \\
(\max 10)\end{array}$ & Workers & 5.93 & 5.92 & 5.73 & 5.57 & 5.51 & 5.13 & 5.00 & 4.80 \\
\hline $\begin{array}{l}\text { Serial } 7 \text { score }(\max \\
5)\end{array}$ & Workers & 4.23 & 4.05 & 3.97 & 3.97 & 4.47 & 4.37 & 4.26 & 4.19 \\
\hline $\begin{array}{l}\text { Finlit Total Correct } \\
(\max 2)\end{array}$ & Workers & 1.19 & 1.24 & 1.27 & 1.24 & 1.59 & 1.49 & 1.43 & 1.32 \\
\hline Subjective LE (\%) & Workers & 0.48 & 0.48 & 0.51 & 0.55 & 0.63 & 0.69 & 0.66 & 0.75 \\
\hline Married (\%) & Workers & 0.79 & 0.81 & 0.81 & 0.80 & 0.85 & 0.89 & 0.90 & 0.91 \\
\hline Living with kids $(\%)$ & Workers & 0.48 & 0.34 & 0.26 & 0.15 & 0.63 & 0.56 & 0.43 & 0.42 \\
\hline Fin. wealth $<\$ 0(\%)$ & Workers & 0.27 & 0.25 & 0.19 & 0.17 & 0.04 & 0.04 & 0.00 & 0.02 \\
\hline $\begin{array}{l}\text { Fin. wealth } \$ 0-\$ 100 \mathrm{k} \\
(\%)\end{array}$ & Workers & 0.60 & 0.57 & 0.58 & 0.57 & 0.85 & 0.73 & 0.75 & 0.79 \\
\hline $\begin{array}{l}\text { Fin.wealth \$100- } \\
\text { \$200k (\%) }\end{array}$ & Workers & 0.04 & 0.07 & 0.09 & 0.10 & 0.07 & 0.12 & 0.15 & 0.12 \\
\hline $\begin{array}{l}\text { Fin. wealth }>=\$ 200 \mathrm{k} \\
(\%)\end{array}$ & Workers & 0.09 & 0.11 & 0.14 & 0.16 & 0.04 & 0.10 & 0.10 & 0.07 \\
\hline
\end{tabular}


(continued)

\begin{tabular}{|c|c|c|c|c|c|c|c|c|c|}
\hline \multirow{2}{*}{$\begin{array}{l}\text { Women } \\
\text { Variable }\end{array}$} & \multirow[b]{2}{*}{ Sample } & \multicolumn{3}{|c|}{ HRS } & \multicolumn{5}{|c|}{ JST AR } \\
\hline & & $50-55$ & $56-60$ & $61-65$ & $66-70$ & $50-55$ & $56-60$ & $61-65$ & $66-70$ \\
\hline Work hours & Total & 38.21 & 38.50 & 37.56 & 35.50 & 34.89 & 32.96 & 29.77 & 29.16 \\
\hline $\begin{array}{l}\text { \% Reporting work } \\
\text { hours }\end{array}$ & Total & 0.66 & 0.56 & 0.30 & 0.13 & 0.67 & 0.62 & 0.40 & 0.23 \\
\hline $\begin{array}{l}\text { Self-rep. health }<\text { av. } \\
(\%)\end{array}$ & Workers & 0.14 & 0.19 & 0.15 & 0.17 & 0.10 & 0.10 & 0.11 & 0.17 \\
\hline $\mathrm{BMI}>=25$ & Workers & 0.69 & 0.69 & 0.70 & 0.69 & 0.19 & 0.19 & 0.20 & 0.28 \\
\hline $\mathrm{BMI}>=30$ & Workers & 0.38 & 0.37 & 0.31 & 0.33 & 0.01 & 0.01 & 0.01 & 0.06 \\
\hline Low education & Workers & 0.39 & 0.44 & 0.47 & 0.60 & 0.71 & 0.79 & 0.87 & 0.90 \\
\hline High education & Workers & 0.61 & 0.56 & 0.53 & 0.40 & 0.29 & 0.21 & 0.13 & 0.10 \\
\hline $\begin{array}{l}\text { Word recall score } \\
(\max 10)\end{array}$ & Workers & 6.39 & 6.20 & 6.36 & 5.96 & 5.76 & 5.68 & 5.41 & 5.06 \\
\hline $\begin{array}{l}\text { Serial } 7 \text { score (max } \\
5)\end{array}$ & Workers & 3.75 & 3.83 & 3.91 & 3.37 & 4.44 & 4.30 & 4.03 & 3.94 \\
\hline $\begin{array}{l}\text { Finlit Total Correct } \\
(\max 2)\end{array}$ & Workers & 1.07 & 1.07 & 1.07 & 1.00 & 1.40 & 1.34 & 1.17 & 1.17 \\
\hline Subjective LE $(\%)$ & Workers & 0.30 & 0.34 & 0.41 & 0.54 & 0.55 & 0.63 & 0.69 & 0.76 \\
\hline Married (\%) & Workers & 0.74 & 0.61 & 0.64 & 0.47 & 0.78 & 0.77 & 0.78 & 0.66 \\
\hline Living with kids (\%) & Workers & 0.46 & 0.30 & 0.22 & 0.22 & 0.59 & 0.52 & 0.48 & 0.53 \\
\hline Fin. wealth $<\$ 0(\%)$ & Workers & 0.28 & 0.25 & 0.23 & 0.19 & 0.05 & 0.03 & 0.04 & 0.00 \\
\hline $\begin{array}{l}\text { Fin. wealth } \$ 0-\$ 100 \mathrm{k} \\
(\%)\end{array}$ & Workers & 0.56 & 0.60 & 0.57 & 0.66 & 0.81 & 0.83 & 0.83 & 0.84 \\
\hline $\begin{array}{l}\text { Fin.wealth } \$ 100- \\
\$ 200 \mathrm{k}(\%)\end{array}$ & Workers & 0.05 & 0.07 & 0.09 & 0.05 & 0.10 & 0.09 & 0.09 & 0.08 \\
\hline $\begin{array}{l}\text { Fin. wealth }>=\$ 200 \mathrm{k} \\
(\%)\end{array}$ & Workers & 0.10 & 0.08 & 0.11 & 0.10 & 0.03 & 0.05 & 0.04 & 0.08 \\
\hline
\end{tabular}


Appendix Table 2. Retirement in Japan and the US: Self-reported Retirement by Sex (unweighted)

\begin{tabular}{|c|c|c|c|c|c|c|c|c|c|}
\hline \multirow{2}{*}{$\begin{array}{l}\text { Men } \\
\text { Variable }\end{array}$} & \multirow[b]{2}{*}{ Sample } & \multicolumn{3}{|c|}{ HRS } & \multicolumn{5}{|c|}{ JSTAR } \\
\hline & & $50-55$ & $56-60$ & $61-65$ & $66-70$ & $50-55$ & $56-60$ & $61-65$ & $66-70$ \\
\hline $\begin{array}{l}\text { Self-rep. retirement } \\
(\%)\end{array}$ & Total & 0.14 & 0.19 & 0.42 & 0.62 & 0.00 & 0.01 & 0.18 & 0.33 \\
\hline \multirow{3}{*}{$\begin{array}{l}\text { Self-rep. health }<\text { av. } \\
(\%)\end{array}$} & Total & 0.23 & 0.28 & 0.23 & 0.28 & 0.09 & 0.14 & 0.17 & 0.21 \\
\hline & Working & 0.14 & 0.18 & 0.15 & 0.18 & 0.08 & 0.11 & 0.10 & 0.13 \\
\hline & Retired & 0.50 & 0.54 & 0.31 & 0.34 & & 0.29 & 0.18 & 0.24 \\
\hline \multirow[t]{3}{*}{$\mathrm{BM} \mathrm{I}>=25$} & Total & 0.78 & 0.81 & 0.79 & 0.76 & 0.30 & 0.26 & 0.29 & 0.28 \\
\hline & Working & 0.80 & 0.82 & 0.82 & 0.74 & 0.29 & 0.26 & 0.30 & 0.26 \\
\hline & Retired & 0.74 & 0.81 & 0.77 & 0.76 & & 0.43 & 0.26 & 0.30 \\
\hline \multirow[t]{3}{*}{ Education (y ears) } & Total & 13.40 & 13.51 & 13.14 & 12.62 & 13.05 & 12.04 & 11.13 & 10.15 \\
\hline & Working & 13.77 & 13.83 & 13.40 & 13.11 & 13.06 & 12.05 & 11.25 & 9.98 \\
\hline & Retired & 12.51 & 12.45 & 12.67 & 12.40 & & 12.57 & 11.15 & 10.85 \\
\hline \multirow[t]{3}{*}{$\begin{array}{l}\text { Word recall score (max } \\
10)\end{array}$} & Total & 5.70 & 5.70 & 5.55 & 5.20 & 5.46 & 5.14 & 4.86 & 4.65 \\
\hline & Working & 5.93 & 5.92 & 5.73 & 5.57 & 5.51 & 5.13 & 5.00 & 4.80 \\
\hline & Retired & 5.18 & 5.10 & 5.32 & 4.99 & & 4.75 & 4.35 & 4.45 \\
\hline \multirow[t]{3}{*}{ Serial 7 score $(\max 5)$} & Total & 3.95 & 3.86 & 3.83 & 3.69 & 4.46 & 4.37 & 4.21 & 4.07 \\
\hline & Working & 4.23 & 4.05 & 3.97 & 3.97 & 4.47 & 4.37 & 4.26 & 4.19 \\
\hline & Retired & 3.16 & 3.25 & 3.60 & 3.57 & & 4.71 & 4.26 & 3.98 \\
\hline \multirow[t]{3}{*}{$\begin{array}{l}\text { Finlit Total Correct } \\
(\max 2)\end{array}$} & Total & 1.18 & 1.21 & 1.21 & 1.17 & 1.60 & 1.48 & 1.42 & 1.39 \\
\hline & Working & 1.19 & 1.24 & 1.27 & 1.24 & 1.59 & 1.49 & 1.43 & 1.32 \\
\hline & Retired & 1.10 & 1.12 & 1.12 & 1.14 & & 1.60 & 1.48 & 1.42 \\
\hline \multirow[t]{3}{*}{ Subjective LE (\%) } & Total & 0.45 & 0.43 & 0.47 & 0.50 & 0.63 & 0.68 & 0.65 & 0.74 \\
\hline & Working & 0.48 & 0.48 & 0.51 & 0.55 & 0.63 & 0.69 & 0.66 & 0.75 \\
\hline & Retired & 0.34 & 0.30 & 0.41 & 0.46 & & 0.71 & 0.75 & 0.74 \\
\hline \multirow[t]{3}{*}{ Married (\%) } & Total & 0.75 & 0.77 & 0.79 & 0.77 & 0.84 & 0.88 & 0.88 & 0.90 \\
\hline & Working & 0.79 & 0.81 & 0.81 & 0.80 & 0.85 & 0.89 & 0.90 & 0.91 \\
\hline & Retired & 0.69 & 0.65 & 0.77 & 0.76 & & 0.86 & 0.87 & 0.91 \\
\hline \multirow[t]{3}{*}{ Living with kids (\%) } & Total & 0.45 & 0.32 & 0.21 & 0.14 & 0.62 & 0.55 & 0.39 & 0.37 \\
\hline & Working & 0.48 & 0.34 & 0.26 & 0.15 & 0.63 & 0.56 & 0.43 & 0.42 \\
\hline & Retired & 0.35 & 0.25 & 0.19 & 0.14 & & 0.71 & 0.28 & 0.34 \\
\hline \multirow[t]{3}{*}{ Fin. wealth $<\$ 0(\%)$} & Total & 0.28 & 0.25 & 0.20 & 0.15 & 0.03 & 0.04 & 0.02 & 0.03 \\
\hline & Working & 0.27 & 0.25 & 0.19 & 0.17 & 0.04 & 0.04 & 0.00 & 0.02 \\
\hline & Retired & 0.31 & 0.25 & 0.20 & 0.15 & & 0.00 & 0.06 & 0.03 \\
\hline \multirow[t]{3}{*}{$\begin{array}{l}\text { Fin. wealth } \$ 0-\$ 100 \mathrm{k} \\
(\%)\end{array}$} & Total & 0.60 & 0.58 & 0.58 & 0.59 & 0.86 & 0.73 & 0.73 & 0.80 \\
\hline & Working & 0.60 & 0.57 & 0.58 & 0.57 & 0.85 & 0.73 & 0.75 & 0.79 \\
\hline & Retired & 0.58 & 0.62 & 0.61 & 0.60 & & 0.50 & 0.69 & 0.80 \\
\hline \multirow[t]{3}{*}{$\begin{array}{l}\text { Fin.wealth } \$ 100-\$ 200 k \\
(\%)\end{array}$} & Total & 0.04 & 0.07 & 0.06 & 0.09 & 0.07 & 0.13 & 0.14 & 0.11 \\
\hline & Working & 0.04 & 0.07 & 0.09 & 0.10 & 0.07 & 0.12 & 0.15 & 0.12 \\
\hline & Retired & 0.04 & 0.04 & 0.05 & 0.10 & & 0.50 & 0.17 & 0.13 \\
\hline \multirow[t]{3}{*}{$\begin{array}{l}\text { Fin. wealth }>=\$ 200 \mathrm{k} \\
(\%)\end{array}$} & Total & 0.08 & 0.10 & 0.15 & 0.17 & 0.04 & 0.10 & 0.10 & 0.05 \\
\hline & Working & 0.09 & 0.11 & 0.14 & 0.16 & 0.04 & 0.10 & 0.10 & 0.07 \\
\hline & Retired & 0.07 & 0.09 & 0.15 & 0.15 & & 0.00 & 0.09 & 0.04 \\
\hline
\end{tabular}


(continued)

\begin{tabular}{|c|c|c|c|c|c|c|c|c|c|}
\hline \multirow{2}{*}{$\begin{array}{l}\text { Women } \\
\text { Variable }\end{array}$} & \multirow[b]{2}{*}{ Sample } & \multicolumn{3}{|c|}{ HRS } & \multicolumn{5}{|c|}{ JST AR } \\
\hline & & $50-55$ & $56-60$ & $61-65$ & $66-70$ & $50-55$ & $56-60$ & $61-65$ & $66-70$ \\
\hline \multirow{4}{*}{$\begin{array}{l}\text { Self-rep. retirement } \\
(\%) \\
\text { Self-rep. health < av. } \\
(\%)\end{array}$} & Total & 0.11 & 0.21 & 0.46 & 0.63 & 0.01 & 0.01 & 0.04 & 0.04 \\
\hline & Total & 0.24 & 0.29 & 0.25 & 0.29 & 0.14 & 0.14 & 0.15 & 0.24 \\
\hline & Working & 0.14 & 0.19 & 0.15 & 0.17 & 0.10 & 0.10 & 0.11 & 0.17 \\
\hline & Retired & 0.46 & 0.46 & 0.30 & 0.33 & 0.33 & 0.00 & 0.29 & 0.20 \\
\hline \multirow[t]{3}{*}{$\mathrm{BMI}>=25$} & Total & 0.70 & 0.72 & 0.73 & 0.70 & 0.19 & 0.20 & 0.21 & 0.26 \\
\hline & Working & 0.69 & 0.69 & 0.70 & 0.69 & 0.19 & 0.19 & 0.20 & 0.28 \\
\hline & Retired & 0.70 & 0.81 & 0.75 & 0.70 & 0.00 & 0.00 & 0.07 & 0.20 \\
\hline \multirow[t]{3}{*}{ Education (years) } & Total & 13.10 & 13.03 & 12.71 & 12.25 & 12.40 & 11.40 & 10.39 & 9.29 \\
\hline & Working & 13.58 & 13.46 & 13.36 & 12.44 & 12.45 & 11.40 & 10.53 & 9.01 \\
\hline & Retired & 12.83 & 12.73 & 12.60 & 12.32 & 11.33 & 13.00 & 10.57 & 9.20 \\
\hline \multirow[t]{3}{*}{$\begin{array}{l}\text { Word recall score } \\
(\max 10)\end{array}$} & Total & 6.23 & 6.09 & 6.04 & 5.69 & 5.79 & 5.63 & 5.34 & 5.20 \\
\hline & Working & 6.39 & 6.20 & 6.36 & 5.96 & 5.76 & 5.68 & 5.41 & 5.06 \\
\hline & Retired & 6.12 & 5.99 & 5.91 & 5.67 & 6.00 & & 6.09 & 5.00 \\
\hline \multirow[t]{3}{*}{ Serial 7 score $(\max 5)$} & Total & 3.54 & 3.66 & 3.51 & 3.25 & 4.45 & 4.25 & 4.13 & 4.02 \\
\hline & Working & 3.75 & 3.83 & 3.91 & 3.37 & 4.44 & 4.30 & 4.03 & 3.94 \\
\hline & Retired & 3.25 & 3.47 & 3.44 & 3.25 & 3.00 & 5.00 & 4.21 & 3.73 \\
\hline \multirow[t]{3}{*}{$\begin{array}{l}\text { Finlit Total Correct } \\
(\max 2)\end{array}$} & Total & 1.05 & 1.06 & 1.05 & 1.01 & 1.39 & 1.36 & 1.30 & 1.22 \\
\hline & Working & 1.07 & 1.07 & 1.07 & 1.00 & 1.40 & 1.34 & 1.17 & 1.17 \\
\hline & Retired & 1.01 & 1.04 & 1.03 & 1.00 & 1.00 & 2.00 & 1.75 & 1.50 \\
\hline \multirow[t]{3}{*}{ Subjective LE (\%) } & Total & 0.29 & 0.30 & 0.39 & 0.46 & 0.51 & 0.61 & 0.68 & 0.70 \\
\hline & Working & 0.30 & 0.34 & 0.41 & 0.54 & 0.55 & 0.63 & 0.69 & 0.76 \\
\hline & Retired & 0.31 & 0.22 & 0.36 & 0.44 & 0.67 & 1.00 & 0.79 & 0.64 \\
\hline \multirow[t]{3}{*}{ Married (\%) } & Total & 0.72 & 0.64 & 0.67 & 0.55 & 0.81 & 0.78 & 0.80 & 0.69 \\
\hline & Working & 0.74 & 0.61 & 0.64 & 0.47 & 0.78 & 0.77 & 0.78 & 0.66 \\
\hline & Retired & 0.65 & 0.59 & 0.68 & 0.55 & 1.00 & 0.50 & 0.50 & 0.33 \\
\hline \multirow[t]{3}{*}{ Living with kids (\%) } & Total & 0.45 & 0.27 & 0.20 & 0.19 & 0.61 & 0.49 & 0.43 & 0.41 \\
\hline & Working & 0.46 & 0.30 & 0.22 & 0.22 & 0.59 & 0.52 & 0.48 & 0.53 \\
\hline & Retired & 0.31 & 0.20 & 0.18 & 0.18 & 0.67 & 0.50 & 0.36 & 0.40 \\
\hline \multirow[t]{3}{*}{ Fin. wealth $<\$ 0(\%)$} & Total & 0.27 & 0.24 & 0.19 & 0.16 & 0.04 & 0.04 & 0.02 & 0.01 \\
\hline & Working & 0.28 & 0.25 & 0.23 & 0.19 & 0.05 & 0.03 & 0.04 & 0.00 \\
\hline & Retired & 0.25 & 0.22 & 0.17 & 0.15 & 0.00 & 0.00 & 0.00 & 0.00 \\
\hline \multirow{3}{*}{$\begin{array}{l}\text { Fin. wealth } \$ 0-\$ 100 k \\
(\%)\end{array}$} & Total & 0.57 & 0.61 & 0.58 & 0.64 & 0.80 & 0.78 & 0.78 & 0.85 \\
\hline & Working & 0.56 & 0.60 & 0.57 & 0.66 & 0.81 & 0.83 & 0.83 & 0.84 \\
\hline & Retired & 0.60 & 0.61 & 0.56 & 0.65 & 0.00 & 1.00 & 0.67 & 0.83 \\
\hline \multirow[t]{3}{*}{$\begin{array}{l}\text { Fin.wealth } \$ 100- \\
\$ 200 \mathrm{k}(\%)\end{array}$} & Total & 0.05 & 0.06 & 0.08 & 0.07 & 0.09 & 0.12 & 0.16 & 0.08 \\
\hline & Working & 0.05 & 0.07 & 0.09 & 0.05 & 0.10 & 0.09 & 0.09 & 0.08 \\
\hline & Retired & 0.02 & 0.07 & 0.09 & 0.07 & 0.33 & 0.00 & 0.22 & 0.17 \\
\hline \multirow{3}{*}{$\begin{array}{l}\text { Fin. wealth }>=\$ 200 \mathrm{k} \\
(\%)\end{array}$} & Total & 0.10 & 0.09 & 0.16 & 0.13 & 0.06 & 0.06 & 0.04 & 0.07 \\
\hline & Working & 0.10 & 0.08 & 0.11 & 0.10 & 0.03 & 0.05 & 0.04 & 0.08 \\
\hline & Retired & 0.13 & 0.11 & 0.19 & 0.13 & 0.67 & 0.00 & 0.11 & 0.00 \\
\hline
\end{tabular}


Appendix Table 3. Hours of Work by Worker Characteristics: by Sex (unweighted)

Men

Variable

Work time

Age 50-55

Age 56-60

Age 61-65

Age 66-70

Self-rep. health $<$ av. (\%)

BMI

$\mathrm{BMI}>=25$

$\mathrm{BMI}>=30$

Low education

High education

Word recall score $(\max 10)$

Serial 7 score $(\max 5)$

Finlit Total Correct $(\max 2)$

Subjective LE (\%)

Married (\%)

Living with kids (\%)

Financial wealth $<\$ 0(\%)$

Fin. wealth $\$ 0-\$ 100 \mathrm{k}(\%)$

Fin.wealth \$100-\$200k (\%)

Fin. wealth $>=\$ 200 \mathrm{k}(\%)$

\begin{tabular}{|c|c|c|c|c|c|c|}
\multicolumn{1}{c}{} & \multicolumn{1}{c}{ HRS } \\
\cline { 2 - 7 } Sample & Full-time & Part-time & All & Full-time & Part-time & All \\
\hline Workers & 24.26 & 46.39 & 44.77 & 18.81 & 49.59 & 45.15 \\
\hline Workers & 0.22 & 0.24 & 0.24 & 0.07 & 0.29 & 0.25 \\
\hline Workers & 0.36 & 0.40 & 0.39 & 0.19 & 0.41 & 0.37 \\
\hline Workers & 0.15 & 0.19 & 0.19 & 0.31 & 0.19 & 0.21 \\
\hline Workers & 0.27 & 0.17 & 0.18 & 0.43 & 0.12 & 0.17 \\
\hline Workers & 0.15 & 0.17 & 0.16 & 0.16 & 0.10 & 0.11 \\
\hline Workers & 27.69 & 28.84 & 28.77 & 23.41 & 23.58 & 23.54 \\
\hline Workers & 0.71 & 0.81 & 0.80 & 0.25 & 0.28 & 0.28 \\
\hline Workers & 0.29 & 0.34 & 0.34 & 0.03 & 0.03 & 0.03 \\
\hline Workers & 0.33 & 0.39 & 0.38 & 0.75 & 0.66 & 0.68 \\
\hline Workers & 0.67 & 0.61 & 0.62 & 0.25 & 0.34 & 0.32 \\
\hline Workers & 5.62 & 5.83 & 5.82 & 4.94 & 5.19 & 5.13 \\
\hline Workers & 4.06 & 4.06 & 4.06 & 4.36 & 4.37 & 4.34 \\
\hline Workers & 1.22 & 1.23 & 1.23 & 1.51 & 1.49 & 1.49 \\
\hline Workers & 0.60 & 0.49 & 0.50 & 0.66 & 0.69 & 0.68 \\
\hline Workers & 0.80 & 0.81 & 0.80 & 0.92 & 0.88 & 0.88 \\
\hline Workers & 0.28 & 0.33 & 0.33 & 0.44 & 0.55 & 0.53 \\
\hline Workers & 0.21 & 0.23 & 0.23 & 0.01 & 0.03 & 0.03 \\
\hline Workers & 0.57 & 0.58 & 0.58 & 0.72 & 0.78 & 0.78 \\
\hline Workers & 0.09 & 0.07 & 0.07 & 0.16 & 0.11 & 0.11 \\
\hline Workers & 0.12 & 0.12 & 0.12 & 0.11 & 0.08 & 0.08 \\
\hline
\end{tabular}


(continued)

Women

Variable

Work time

Age 50-55

Age 56-60

Age 61-65

Age 66-70

Self-rep. health $<$ av. $(\%)$

BMI

BMI $>=25$

BMI $>=30$

Low education

High education

Word recall score $(\max 10)$

Serial 7 score $(\max 5)$

Finlit Total Correct $(\max 2)$

Subjective LE (\%)

Married (\%)

Living with kids (\%)

Financial wealth $<\$ 0(\%)$

Fin. wealth $\$ 0-\$ 100 \mathrm{k}(\%)$

Fin.wealth \$100-\$200k (\%)

Fin. wealth $>=\$ 200 \mathrm{k}(\%)$

HRS

JST AR

\begin{tabular}{|c|cccc|c|c|c|}
\cline { 2 - 7 } \multicolumn{1}{c|}{ Sample } & Full-time & Part-time & All & Full-time & Part-time & All \\
\hline Workers & 22.96 & 42.59 & 37.88 & 19.52 & 45.56 & 32.35 \\
\hline Workers & 0.31 & 0.32 & 0.31 & 0.25 & 0.37 & 0.30 \\
\hline Workers & 0.32 & 0.40 & 0.37 & 0.32 & 0.36 & 0.32 \\
\hline Workers & 0.20 & 0.19 & 0.19 & 0.26 & 0.19 & 0.23 \\
\hline Workers & 0.17 & 0.10 & 0.12 & 0.16 & 0.08 & 0.15 \\
\hline Workers & 0.17 & 0.16 & 0.16 & 0.12 & 0.10 & 0.11 \\
\hline Workers & 27.83 & 28.75 & 28.52 & 22.67 & 22.68 & 22.75 \\
\hline Workers & 0.63 & 0.71 & 0.69 & 0.21 & 0.18 & 0.20 \\
\hline Workers & 0.32 & 0.37 & 0.36 & 0.02 & 0.02 & 0.02 \\
\hline Workers & 0.48 & 0.44 & 0.45 & 0.81 & 0.79 & 0.80 \\
\hline Workers & 0.52 & 0.56 & 0.55 & 0.19 & 0.21 & 0.20 \\
\hline Workers & 6.21 & 6.28 & 6.26 & 5.60 & 5.61 & 5.55 \\
\hline Workers & 3.84 & 3.75 & 3.76 & 4.23 & 4.25 & 4.23 \\
\hline Workers & 1.05 & 1.07 & 1.06 & 1.28 & 1.38 & 1.31 \\
\hline Workers & 0.36 & 0.36 & 0.37 & 0.61 & 0.64 & 0.64 \\
\hline Workers & 0.71 & 0.62 & 0.64 & 0.79 & 0.72 & 0.76 \\
\hline Workers & 0.33 & 0.32 & 0.32 & 0.56 & 0.50 & 0.53 \\
\hline Workers & 0.22 & 0.26 & 0.25 & 0.02 & 0.06 & 0.04 \\
\hline Workers & 0.60 & 0.58 & 0.59 & 0.82 & 0.81 & 0.83 \\
\hline Workers & 0.07 & 0.07 & 0.07 & 0.09 & 0.11 & 0.09 \\
\hline Workers & 0.11 & 0.09 & 0.10 & 0.06 & 0.03 & 0.05 \\
\hline
\end{tabular}

